\title{
Automated Processing of Doppler Radar Data for Severe Weather Warnings
}

\author{
Paul Joe', Sandy Dance², Valliappa Lakshmanan ${ }^{3}$, Dirk Heizenreder ${ }^{4}$, \\ Paul James ${ }^{4}$, Peter Lang4, Thomas Hengstebeck4, Yerong Feng5, P.W. Li6, \\ Hon-Yin Yeung, ${ }^{6}$ Osamu Suzuki ${ }^{7}, \mathrm{Keiji} \mathrm{Doi}^{7}$ and Jianhua Dai ${ }^{8}$ \\ ${ }^{1}$ Environment Canada \\ ${ }^{2}$ Bureau of Meteorology, \\ ${ }^{3} \mathrm{CIMMS} / \mathrm{OU} /$ National Severe Storms Laboratory, \\ ${ }^{4}$ Deutcher Wetterdienst, \\ ${ }^{5}$ Guandong Meteorological Bureau, China Meteorological Agency, \\ ${ }^{6}$ Hong Kong Observatory, \\ 7Japan Meteorological Agency, \\ ${ }^{8}$ Shanghai Meteorological Bureau, China Meteorological Agency, \\ ${ }^{1}$ Canada \\ ${ }^{2}$ Australia \\ ${ }^{3}$ USA \\ ${ }^{4}$ Germany \\ 7Japan \\ $5,6,8$ China
}

\section{Introduction}

Radar is the only operational tool that provides observations of severe weather producing thunderstorms on a fine enough temporal or spatial resolution (minutes and kilometers) that enables warnings of severe weather. It can provide a three- dimensional view about every five to ten minutes at a spatial resolution of the order of $1 \mathrm{~km}$ or less. The development and evolution of intense convective precipitation is closely linked to thunderstorms and so understanding of the microphysics and dynamics of precipitation is needed to understand the evolution of thunderstorms as diabatic and precipitation processes modify and create hazardous rain, hail, wind and lightning.

The characteristics and proportion of severe weather is climatologically or geographically dependent. For example, the highest incidence of tornadoes is in the central U.S. whereas the tallest thunderstorms are found in Argentina (Zipser et al, 2006). Warning services developed at National Hydrological and Meteorological Services (NHMS) often originate because of a particular damaging severe weather event and ensuing expectations of the public. Office organization, resources and expertise are critical considerations in the use of radar for the preparation of severe weather warnings. Warnings also imply a level of legal liability requiring the authority of an operational National Hydrological Meteorological 
Service. All available data and timely access is critical and requires substantial infrastructure, ongoing support and maintenance. Besides meteorological data, eye witness observations and reports are also essential element in the issuance of tornado warnings (Doswell et al, 1999; Moller, 1978).

This contribution will discuss operational or operational prototypical radar processing, visualization systems for the production of convective severe weather warnings. The focus will be on the severe weather identification algorithms, the underlying philosophy for its usage, the level of expertise required, decision-making and the preparation of the warning. Radar is also used for the precipitation estimation and its application for flash flood warnings. This is discussed elsewhere (Wilson and Brandes, 1979). Only a few countries have convective thunderstorm warning services and the target audience for this contribution are those countries or NHMS' considering developing such a service. The intent is to provide a broad overview and global survey of radar processing systems for the provision of severe weather warning services. There is a considerable literature in convective weather forecasting and warning, this contribution can only explore a few aspects of this topic (Doswell, 1982: Doswell, 1985; Johns and Doswell, 1992; Wilson et al, 1998).

The forecasting and the warning of severe weather are very briefly described. Then, the underlying technique for the identification of severe thunderstorms using radar is presented. This forms the basis for the radar algorithms that identify the severe storm features. The basic components of the system are then described. Some details and unique innovations are incorporated in the global survey of operational or near operational use. This is concluded by a summary.

\section{Forecasting/Nowcasting/Severe weather warnings}

Severe weather predictions are divided into severe weather watches and severe weather warnings. In the preceding days, thunderstorm outlooks may be issued. Watches are predictions of the potential of severe weather. They are strategic in nature and fairly coarse in spatial and temporal resolution. They are often issued on a schedule or in conjunction with the public forecast. The expected behaviour is that the public would be aware of the possibility of severe weather and to listen for future updates. Warnings are predictions of the occurrence or imminent occurrence (with high certainty) of severe weather. They are tactical and more specific in location and time. They are also specific in weather element. They are a call to action and to protect one's property and one's self. They are issued and updated as necessary. Fig. 1 shows an overview of the process from the Japanese Meteorological Agency.

Weather advisories are issued if the weather is a concern but not hazardous. Specific types of warning, such as tornado or hail warnings may then be issued and generally after the more generic severe thunderstorm warning is issued.

The key difference is that the watch is a forecast or very short range forecast service as strategic in nature whereas the warning is a nowcast (based on existing data, precise in time, location and weather element) and tactical in nature. 


\subsection{Severe weather definition}

Severe weather is defined here as heavy rains, hail, strong winds including tornadoes and lightning. In the production of warnings, thresholds need to be defined. The thresholds are necessarily locally defined by climatology, local infrastructure and familiarity will dictate what is extreme. Table 1-4 show the warning criteria for Canada circa 1995. Canada is a very big country covering many different weather climatologies and therefore is illustrative of the variation of the severe weather thresholds (see also Galway, 1989). For example, Newfoundland on the east coast of Canada is a very windy location and hence strong winds are a common occurrence and the people have adapted to their environment and therefore it has the highest wind threshold in Canada. Each service needs to define these for them selves.


Fig. 1. The envisioned warning process from outlook to tornado watch. This is typical of the process that is used in most countries providing severe weather warning services. Getting the message out to and understood by the public is very important aspect of the utility of the warning service. Superimposing the warning on television, internet, mobile devices and directed messaging are critical to have the message heard. 


\begin{tabular}{ll}
\hline Type & Description \\
\hline \hline Wind & $\begin{array}{l}\text { Strong winds that cause mobility problems and possible damage to vegetation and } \\
\text { structures. }\end{array}$ \\
Heavy Rainfall & $\begin{array}{l}\text { Heavy or prolonged rainfall accumulating on a scale sufficient to cause } \\
\text { local/widespread flooding. } \\
\text { One or more of the following: strong winds causing mobility difficulty, damage to } \\
\text { Thunderstorm }\end{array}$ \\
structures due to wind and hail, heavy rain that may cause local flooding and lightning \\
Presence of tornado(es), damaging hail, heavy rain, strong winds, life and property \\
Tornado
\end{tabular}

Table 1. Severe Weather Criteria in Canada: Warning Elements

\begin{tabular}{|c|c|c|c|c|}
\hline $\begin{array}{l}\text { Weather } \\
\text { Centre }\end{array}$ & Wind & Rain & Hail & Remarks \\
\hline $\begin{array}{l}\text { Newfound- } \\
\text { land }\end{array}$ & $\begin{array}{l}\text { gusts of } \\
90 \\
\mathrm{~km} / \mathrm{h}\end{array}$ & $25 \mathrm{~mm} / \mathrm{h}$ & $20 \mathrm{~mm}$ & $\begin{array}{l}\text { No tornado criteria; no tornado warning; may } \\
\text { mention hurricanes in marine warning. }\end{array}$ \\
\hline Maritimes & $\begin{array}{l}\text { gusts of } \\
90 \\
\mathrm{~km} / \mathrm{h}\end{array}$ & $\begin{array}{l}25 \mathrm{~mm} \text { in } 1 \mathrm{hr} \\
\text { or } 50 \mathrm{~mm} \text { in } 3 \\
\text { hrs }\end{array}$ & $15 \mathrm{~mm}$ & $\begin{array}{l}\text { Tornado or tornadic waterspout; no tornado } \\
\text { warning; will issue hurricane prognostic } \\
\text { message and information statements. }\end{array}$ \\
\hline Quebec & $\begin{array}{l}\text { gusts of } \\
90 \\
\mathrm{~km} / \mathrm{h}\end{array}$ & $\begin{array}{l}25 \mathrm{~mm} \text { in } 1 \mathrm{hr} \\
\text { or } 50 \mathrm{~mm} \text { in } 12 \\
\text { hrs }\end{array}$ & $20 \mathrm{~mm}$ & $\begin{array}{l}\text { Tornado, water spout, funnel cloud, windfall; } \\
\text { no tornado warning }\end{array}$ \\
\hline Ontario & $\begin{array}{l}\text { gusts of } \\
90 \\
\mathrm{~km} / \mathrm{h}\end{array}$ & $\begin{array}{l}50 \mathrm{~mm} / \mathrm{hr} \text { for } 1 \\
\mathrm{hr} ; 75 \mathrm{~mm} \text { for } 3 \\
\mathrm{hrs}\end{array}$ & $20 \mathrm{~mm}$ & $\begin{array}{l}\text { No tornado criteria in severe thunderstorm } \\
\text { warning; tornado watch issued when } \\
\text { confirmed tornadoes threaten to move into } \\
\text { region or issued up to } 6 \text { hours in advance } \\
\text { based on analysis or immediately for severe } \\
\text { thunderstorms that indicate potential for } \\
\text { becoming tornadic; tornado warning on } \\
\text { forecast or observation. }\end{array}$ \\
\hline Prairie & $\begin{array}{l}90 \\
\mathrm{~km} / \mathrm{h}\end{array}$ & $\begin{array}{l}50 \mathrm{~mm} \text { in } 1 \mathrm{hr} \\
75 \mathrm{~mm} \text { in } 3 \mathrm{hr}\end{array}$ & $20 \mathrm{~mm}$ & $\begin{array}{l}\text { Tornado or waterspout probable; tornado } \\
\text { warning issued when expected or observed. } \\
\text { Tornado, waterspout or tornado warning }\end{array}$ \\
\hline Alberta & $\begin{array}{l}\text { gust of } \\
90 \\
\mathrm{~km} / \mathrm{h}\end{array}$ & $30 \mathrm{~mm} / \mathrm{h}$ & $20 \mathrm{~mm}$ & $\begin{array}{l}\text { when observed or expected or waterspout } \\
\text { exists; cold air funnel cloud warning when } \\
\text { cold air funnels expected but not tornadoes. }\end{array}$ \\
\hline Arctic & $\begin{array}{l}90 \\
\mathrm{~km} / \mathrm{h}\end{array}$ & $25 \mathrm{~mm} / \mathrm{hr}$ & $12 \mathrm{~mm}$ & $\begin{array}{l}\text { Tornado, water spout, funnel cloud; tornado } \\
\text { occurrence warning on a confirmed report. }\end{array}$ \\
\hline Yukon & $\begin{array}{l}\text { gust to } \\
90 \\
\mathrm{~km} / \mathrm{h}\end{array}$ & $25 \mathrm{~mm}$ in $2 \mathrm{hr}$ & $\begin{array}{l}\text { significant } \\
\text { hail }\end{array}$ & $\begin{array}{l}\text { Potential of tornado; warning is for } \\
\text { thunderstorms; no tornado warning. }\end{array}$ \\
\hline Pacific & $\begin{array}{l}\text { gusts of } \\
90 \\
\mathrm{~km} / \mathrm{h}\end{array}$ & $25 \mathrm{~mm}$ in $1 \mathrm{hr}$ & $15 \mathrm{~mm}$ & $\begin{array}{l}\text { Lightning intensity of } 500 \text { strikes in } 1 \text { hr over } \\
\text { an area of } 1 \text { degree x } 1 \text { degree } \\
\text { latitude/longitude; no watches for severe } \\
\text { thunderstorms or tornadoes; no tornado } \\
\text { warnings; thunderstorm warning issued on a } \\
\text { less than severe thunderstorm; will issue } \\
\text { hurricane prognostic messages and } \\
\text { information statements. }\end{array}$ \\
\hline
\end{tabular}

Table 2. Severe Weather Criteria in Canada: Severe Thunderstorm Criteria 


\begin{tabular}{ll}
\hline Weather Centre & Warning Criteria \\
\hline \hline Newfoundland & $50 \mathrm{~mm}$ in $24 \mathrm{hrs}$ \\
Maritimes & $50 \mathrm{~mm}$ in $24 \mathrm{hrs}$ \\
Quebec & $50 \mathrm{~mm}$ in $24 \mathrm{hrs}$ or $30 \mathrm{~mm}$ in $12 \mathrm{hrs}$ during a spring thaw \\
& $50 \mathrm{~mm}$ in $12 \mathrm{hrs}$; sodden ground/ bare frozen ground: $25 \mathrm{~mm}$ in 24 \\
Ontario & hrs; spring: $25 \mathrm{~mm}$ in 24 hrs; slow moving thunderstorms: $50 \mathrm{~mm} / 3$ \\
& hrs or $25 \mathrm{~mm} / 3 \mathrm{hrs}$ if ground is sodden. \\
Prairie & $80 \mathrm{~mm}$ in $24 \mathrm{hrs}$ or $50 \mathrm{~mm}$ in $12 \mathrm{hrs}$ \\
Alberta & $50 \mathrm{~mm}$ in $24 \mathrm{hrs}$ \\
Arctic & $50 \mathrm{~mm}$ in $24 \mathrm{hr}$ \\
Yukon & $40 \mathrm{~mm}$ in $24 \mathrm{hr}$ \\
Pacific & $50 \mathrm{~mm}$ in $24 \mathrm{hr}$ except in west Vancouver Island and northern \\
\hline \hline
\end{tabular}

Table 3. Severe Weather Criteria in Canada: Heavy Rainfall Warning

\begin{tabular}{ll}
\hline Weather Centre & Warning Criteria \\
\hline \hline Newfoundland & $75 \mathrm{~km} / \mathrm{h}$ and/or gusts of $100 \mathrm{~km} / \mathrm{h}$ \\
Maritimes & $65 \mathrm{~km} / \mathrm{h}$ and/or gusts to $90 \mathrm{~km} / \mathrm{h}$ \\
Quebec & $50 \mathrm{~km} / \mathrm{h}$ with gusts to $90 \mathrm{~km} / \mathrm{h}$ or with only gust to $90 \mathrm{~km} / \mathrm{h}$ \\
Ontario & $60 \mathrm{~km} / \mathrm{h}$ for 3 hours, or gusts of $90 \mathrm{~km} / \mathrm{h}$ for $3 \mathrm{hrs}$ \\
Prairie & $60 \mathrm{~km} / \mathrm{h}$ and/or gusts to $90 \mathrm{~km} / \mathrm{h}$ for $1 \mathrm{hr}$ \\
Alberta & $60 \mathrm{~km} / \mathrm{h}$ or gusts to $100 \mathrm{~km} / \mathrm{h}$ except in Lethbridge Region: 70 \\
Arctic & $\mathrm{km} / \mathrm{h}$ or gusts to $120 \mathrm{~km} / \mathrm{h}$. \\
Yukon & $60 \mathrm{~km} / \mathrm{h}$ or gusts of $90 \mathrm{~km} / \mathrm{h}$ \\
& $60 \mathrm{~km} / \mathrm{h}$ for $3 \mathrm{hr}$ or gusts to $90 \mathrm{~km} / \mathrm{h}$ \\
Pacific & Mandatory $90 \mathrm{~km} / \mathrm{h}$ expected over adjacent marine areas; \\
& discretionary if gale force winds $(63$ to $89 \mathrm{~km} / \mathrm{h})$ expected over \\
\hline \hline
\end{tabular}

Table 4. Severe Weather Criteria in Canada: Strong Wind Warning

Warnings for summer severe weather are for extreme or rare events - events that are at the high end of the spectrum of weather. In terms of statistics, rare events do not occur very often (by definition) and so statistical analyses are always suspect due to low numbers. It is difficult to easily demonstrate (using statistics) the efficacy of a warning program (Doswell et al, 1990; Ebert et al 2004). Qualitative analyses or case studies are required to understand the relationship between the provision of warnings and the saving of lives (Sills et al, 2004; Fox et al, 2004). The same applies to determining the efficacy of radar algorithms to the provision of weather warnings (Joe et al, 2004).

This has a significant impact on statistics but also on the "cry wolf" syndrome (AMS, 2001; Barnes et al, 2007; Schumacher et al, 2010; Westefeld et al, 2006). An accurate but useless tornado forecast could be by stating that "next year there will be a tornado in the U.S." This statement is a climatological or statistical forecast. It has a very high probability of being true. However, the phenomenon is very small, perhaps $10-20 \mathrm{~km}$ in length and $500 \mathrm{~m}$ in width and so this particular prediction is not very useful. The information is highly accurate 
but not very precise in terms of location or time. Most, if not all, people would ignore the warning and take the risk. Another form of the "cry wolf" syndrome is where warnings are issued indiscriminately for a very precise time and location and with considerable lead time. However, particularly for rare events (those at the extreme end of a distribution), this is accompanied by a high false alarm rate. If too many false alarms are issued, then these will also be ignored. So, for rare extreme hazardous events, high probability of detection is needed but the false alarms need to be mitigated (Bieringer and Ray, 1996; Black and Ashley, 2011; Glahn 2005; Hoekstra et al, 2011; Polger et al, 1994).

So the issuance of warnings requires a very fine balance of decision-making that takes into account lead time, climatology, societal risk behaviour, social-economic infrastructure, warning service capacity and many other regional, political and societal factors (Baumgart et al, 2008; Dunn, 1990; Hammer and Schmidlin, 2002; Mercer et al, 2009; Schmeits et al, 2008; Westefeld et al, 2006; Wilson et al, 2004). Nowcasts in general are user dependent (Baumgart et al, 2008). Warnings are an extreme kind of nowcasts in which the thresholds apply to a very broad range of users (the public). However, in the future, one can envision very specific warnings or nowcasts issued at lower thresholds that may affect specific users requiring tailored communication techniques and technologies (Keenan et al, 2004; Schumacher et al, 2010).

The wind hazard deserves an extended discussion (Doswell, 2001). There are various kinds of wind hazards that have distinctive life times and spatial features. Straight line winds can originate in synoptic systems or typhoons and are ubiquitous, broad in spatial scale $(\sim 100+$ $\mathrm{km}$ ) and extended in duration ( hours/days). Derechos ${ }^{1}$ are also straight line winds that originate out of mesoscale convective complexes (MCC; Davis et al, 2004; Evans and Doswell, 2001; Przybylinski, 1995; Weisman, 2001). The damaging portion exists at specific locations. They are smaller in size and temporal scale than the previous kind of winds. Gust fronts originate with the downdrafts of MCC's and depending on the nature of the MCC (isolated thunderstorm, multi- cellular, line echo wave pattern, bow echo, pulse storm); the gust front can take on many forms but generally emanate outwards from the MCC (Klingle et al, 1987). They can extend for a long time and there may be extreme winds in portions of the gust front.

The downdrafts can also generate quasi-circular outward flowing winds called downbursts (generic term). If the downbursts are over airports, small in diameter $(<4 \mathrm{~km})$ and intense $(>10 \mathrm{~m} / \mathrm{s}$ velocity differential) then they are given a very specific term called the microburst (McCarthy et al, 1982; Wilson et al, 1988; Wilson and Wakimoto 2001). It is arbitrarily defined this way in order to be very clear to aviators that they are hazardous and should not be transected. They originate with a descending intense precipitation core and the wind intensity is enhanced by evaporative cooling (Byko et al, 2009). If evaporation is strong, by the time the downburst reaches the surface, there may not be any precipitation associated with it. In this case, the feature is called a dry downburst. If there is precipitation then it is called a wet downburst or microburst as the case may be.

There are algorithmic radar techniques for the identification of all of these severe weather features (Dance and Potts, 2002; Donaldson and Desrochers, 1990; Johnson et al, 1998; Joe et

${ }^{1}$ It is beyond the scope of this contribution to illustrate the various severe hazards in detail see references for fourther information. 
al, 2004; Kessler and Wilson, 1971; Lakshmanan et al, 2003; Lakshmanan and Smith, 2009; Lakshmanan et al, 2009; Lenning et al, 1998; Mitchell et al, 1998; Stumpf et al, 1998; Winston, 1998; Witt et al, 1998a, Witt et al, 1998b). The efficacy of the detection depends on the radar scan strategy and quality of the radar (range, azimuth resolution, cycle time, sensitivity, elevation angles, number of elevation tilts, etc (Brown et al, 2000; Heinselman et al, 2008; Lakshmanan et al, 2006; Marshall and Ballantyne, 1975; McLaughlin et al, 2009; Vasiloff, 2001).

\subsection{Watches}

Watches are based on the concept that the juxtaposition of dynamics, thermodynamics and a mechanism to create upward motion and/or a mechanism to remove inhibition factors exists. This is often called the ingredients approach as one looks to see where the various ingredients come together and that is where severe weather will occur. Historically, this is based on the original Fawbush and Miller Technique (1953) but it has gone through significant evolution (Doswell, 1980, 1982, 1985, 2001; Johns and Doswell, 1992; Moller, 2001; Moninger et al, 1991; Monteverdi et al, 2003; Rasmussen, 2003; Weiss et al 1980).

Fig. 2 shows the morphology of thunderstorms that theoretically develop under different wind shear and convective available potential energy (CAPE) situations (Brooks et al, 1993; Brooks et al, 1994; Markowski et al, 1998b; Weisman and Klemp, 1984; Weisman and Rotunno, 2000). Dynamics is represented by the $0-3 \mathrm{~km}$ magnitude of the wind shear. Other height limits may be used depending on the region and local operational usage. The atmospheric structure (low level moisture, mid level dry air, strength of inversions, etc) is important and the thermodynamics is represented by CAPE in this figure. While shear and CAPE are two basic indices that are often used, many other indices are investigated and used.

\section{length of $0-6 \mathrm{~km}$ shear vector $(\mathrm{kt})$}

\begin{tabular}{|c|c|c|c|}
\hline & $<20$ & $20-45$ & $>40$ \\
\hline $\begin{array}{l}\circ \\
\text { ○ } \\
\text { ㅁ }\end{array}$ & ORDINARY & $\begin{array}{l}\text { ORDINARY } \\
\text { OR } \\
\text { MULTICELL }\end{array}$ & $\begin{array}{l}\text { ORDINARY } \\
\text { OR } \\
\text { SUPERCELL }\end{array}$ \\
\hline $\begin{array}{l}0 \\
0 \\
10 \\
N \\
1 \\
0 \\
0 \\
0\end{array}$ & $\begin{array}{c}\text { ORDINARY } \\
\text { WITH SOME } \\
\text { PULSE } \\
\text { SEVERE }\end{array}$ & MULTICELL & SUPERCELL \\
\hline $\begin{array}{l}O \\
0 \\
\stackrel{1}{N} \\
\wedge\end{array}$ & $\begin{array}{c}\text { ORDINARY } \\
\text { WITH SOME } \\
\text { PULSE } \\
\text { SEVERE }\end{array}$ & MULTICELL & SUPERCELL \\
\hline
\end{tabular}

Fig. 2. Thunderstorm type as a function of CAPE and Shear. 
Watches are generally very broad in spatial nature due to the spatial density of the observations (soundings and surface observation), and models which are based on the observations, which is very sparse. The resulting analysis of severe weather potential is therefore necessarily broad. The situation is also very fluid and there can be many local factors such a topography or land-water boundaries or rural- urban differences, to name just a few (King et al, 2003; Wasula et al, 2002; Wilson et al, 2010). What are very difficult to identify are potential mechanisms to create upward motion (the trigger) or to overcome the convective inhibition (break the cap). On a synoptic scale, this could be lift generated by cold or warm fronts but on a smaller scale, they can be created by dry lines, thunderstorm outflows, lake-land breezes, urban hot spots, etc. Often they are very low level and therefore hard to observe. So forecasts of severe weather are indications that the potential ingredients exist. They are therefore very broad and strategic in nature.

\subsection{Warnings}

Weather warnings are issued when there is very high likelihood of severe weather. A broadly worded severe weather thunderstorm warning is most often first issued. If appropriate, it is followed by a more specific warning on a particular thunderstorm and specific severe weather element. This approach is not universal but is dependent on the climatology of severe weather and the level of the warning service that can or has been decided to provide. An important aspect of the detail of the warning is the ability to use the information by the end-user, which is often the public. The public may not know how to react. Given the "cry wolf" syndrome, there needs to be an education process (see Fig. 1). Often, a disaster is needed to get the attention of the public but the significance of the event can be lost in a few short years. Civil emergency services and hydro utilities can plan their post- event remediation actions/locations based on the warning areas and products. So, there can be many variations and underlying philosophies for the provision of warning services. This partially drives the design of the radar processing, visualization and warning preparations systems. It is one thing if severe weather is prevalent and there is a dedicated forecaster for a small area and the public is well attuned to the severity of the weather and have tornado shelters (Andra et al, 2002). It is another thing if the forecaster has to cover several radars and dealing with ill informed users (Leduc et al, 2002; Schumacher et al, 2010).

\section{Identifying severe thunderstorms}

\subsection{Lemon technique}

The specificity of the severe thunderstorm warning is primarily based on a radar feature identification technique attributed to Lemon $(1977,1980)$ and is based on a morphological approach (Moller et al, 1994). It is beyond the scope of this contribution to present or describe the various types of thunderstorms (Fig. 3 shows a small sample). As mentioned earlier, precipitation and precipitation cores form aloft and then descend.

The following features need to be identified:

- $\quad$ tilted updraft, and/or weak or bound weak echo region

- displaced echo top relative to the low-mid level core

- $\quad$ strong reflectivity gradients 
- $\quad$ high low level reflectivity core displace towards the updraft

- concavity (hook echo)

- deviant motion (right or left mover, depending on hemisphere)

- rotation

This is a highly condensed version of the technique and there are many subtleties and morphological pathways as storms evolve. Severe storms begin as non-severe storms and algorithm developers and forecasters try very hard to extend lead times by trying to identify the severity of the future storm as early as possible. Note also that it is often in the collapsing stages of the storm (indicated by collapsing echo top or a descending core) when the severe weather reaches the surface (see Fig. 4).

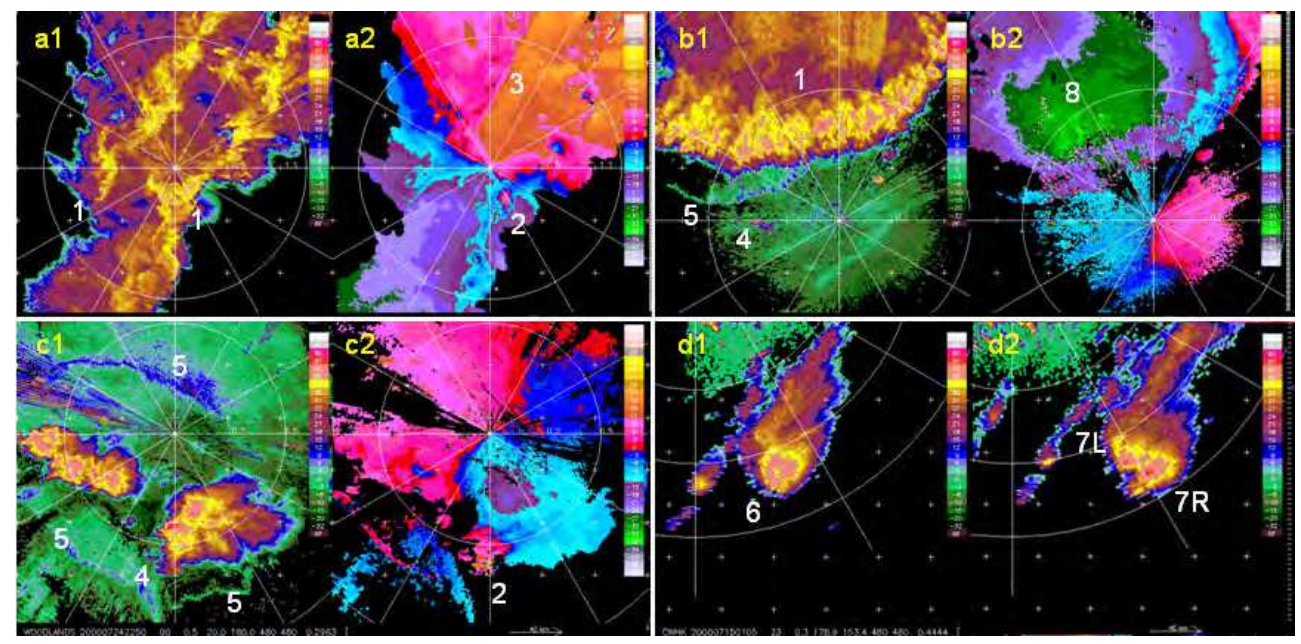

Fig. 3. It is obligatory to show radar images of severe convective storms. Linear convective storms are show in (a) and (b) whereas isolated thunderstorms are shown in (c) and (d). Except for (d), reflectivity and radial velocity images are shown together. Fig. 3a shows double squall lines (1) with embedded cells and mesocyclones (2). (3) shows a shear line associated with a cold frontal passage, so the mesocyclones are pre-frontal and likely to have formed on a previously formed outflow boundary. Fig $3 \mathrm{~b}$ shows embedded thunderstorms on a bow echo. Note the boundaries (5) ahead of the bow echo. (8) shows a meso-scale intense straight line wind (nearing $48 \mathrm{~m} / \mathrm{s}$ ). Fig 3c show an isolated thunderstorm with a mesocyclone (4). Boundaries (5) can be seen and to be associated with the entire mesoscale convective complex and not just one individual cell. Fig. $3 \mathrm{~d}$ shows the splitting of an isolated tornado producing storm. The yellow shading is the 40 $\mathrm{dBZ}$ contour. Often, cell identification thresholds are set lower ( 30 or $35 \mathrm{dBZ}$ ) in an attempt to get earlier cell detections but this demonstrates that this results in detecting different storm structures.

Not discussed here is the identification of the initiation phase of convective weather (Wilson et al, 1998). Significant progress has been made in the warning of air mass thunderstorms. In the past, these were considered random and unforecastable. Wilson et al (1998) demonstrate that they are not random but form on boundaries (see the fine lines on Fig. 3c). Roberts et al 
(2006) discuss the tools to help bridge the convective initiation phase to the severe phase of thunderstorm nowcasting. The science or theory of thunderstorm is still evolving (Brooks et al, 1994; Brunner et al, 2007; Markowski, 2002; Rasmussen et al, 1994; Weisman and Rotunno, 2004).


0

Time [minutes]

Fig. 4. A time-height diagram through the core of a long lived thunderstorm with a mesocyclone. The "nose" on the left side of the shading indicates the precipitation and the mesocyclone originate at mid-levels of the atmosphere and develop vertically up and down. In the collapse phase of the storm or mesocyclone top, the severe weather reaches the ground (adapted from Burgess et al, 1993; Lemon and Doswell, 1979).

\subsection{Other data sets}

This contribution focuses on radar and its use in the preparation of warnings. In fact, all sources of observations and information are used to validate and enforce the conceptual models used to produce the warnings. Satellite imagery, such as provided by MSG and the future GOES-R, will be able to provide 5 minute updates over limited areas. Lightning networks are now prevalent and often used as surrogates for radar data where none is available. They also directly observe the lightning hazard (Branick et al, 1992; Gatlin et al, 2010; Goodman et al, 1988; Knupp et al, 2003; Lang et al, 2004; Schultz et al, 2011;). Even though a single lightning flash can cause serious harm or death, table 2 indicates that, in Canada, a propensity of lightning strikes is needed before a lightning warning will be issued. Surface wind reports can be also used. However, a tornado or a microburst is relatively small and most operational networks are too sparse to effectively sample the atmosphere for such a small feature. At some airports, a dense network of anemometers is established for this specific problem (Wilson et al, 1998). An important data set are eye witness reports (Doswell et al, 1999; Moller 1978; Smith, 1999). In the past, eye witness reports were required before a tornado warning would be issued. This made all tornado warnings "late" with negative lead times. This was done in order not to "cry wolf" and "alarm the public". An emerging source of information is the use of high resolution NWP (Hoekstra et al 2011; Li, 2010; Stensrud et al 2009). While phase errors exist (time and location of the thunderstorm), the models appear to be able to capture the morphology of the storm (see Fig. 2). While radar is the core observation system for severe weather warnings at the convective scale, these are not available everywhere. A warning service that does not include radar has yet to be effectively demonstrated. 


\subsection{Radar dependencies}

The Lemon technique implies that volume scanning radars are needed since many of the critical features originate aloft (see Fig. 4). Both, high data quality (Joe, 2009; Lakshmanan et al, 2007; Lakshmanan et al 2010; Lakshmanan et al, 2011) and rapid update cycles for the fast evolving thunderstorms (Crum and Alberty, 1993; Marshall and Ballantyne, 1975). In order to detect low level "clear air" boundaries important for the identification of convective initiation, high sensitivity is critical. Research literature often shows many examples of extensive clear air radar echoes that are not operationally observed. The operational question is whether it is a radar sensitivity issue or the lack of insect targets (the clear air targets have been identified as insects through dual-polarization signatures). Extensive clear air echoes are commonly reported observed on the WSR-88D and primarily in certain parts of the United States (Wilson et al, 1998). Table 5 shows the sensitivity of a small sample of radars including the WSR-88D, WSR-98D (S Band radars) and three C Band radars, one of which is a low powered $(8 \mathrm{~kW})$, travelling wave tube (TWT) solid sate pulse compression radar (Joe, 2009; Bech et al, 2004; O'Hora and Bech, 2007). In units of dBZ, the sensitivity is a function of range. Fifty kilometer range is arbitrarily chosen to compare the radar sensitivities. The table shows that all these state of the art radars can have comparable sensitivity. Therefore, the apparent lack of clear air echoes is due to the lack of local clear air radar targets and not due to radar sensitivity or wavelength (for example, see May et al, 2004). In addition, due to the dependendence of the backscatter on the inverse frequency squared, C Band radars should observe insects better than S Band radars.

\begin{tabular}{|c|c|}
\hline Radar & MDS at $50 \mathrm{~km}$ \\
\hline "WSR-98D (TJ) & $-6.0 \mathrm{dBZ}$ \\
\hline WSR-98D (BJ) & $-5.5 \mathrm{dBZ}$ \\
\hline WSR-88D (KTLX) & $-7.5 \mathrm{dBZ}$ \\
\hline WSR-88D (KLCH) & $-8.5 \mathrm{dBZ}$ \\
\hline WKR Conventional C Band ( 2 us pulse) & $-11.0 \mathrm{dBZ}$ \\
\hline WKR Conventional C Band ( $0.5 \mu$ s pulse) & $-5.0 \mathrm{dBZ}$ \\
\hline CDV TWT ( $8 \mathrm{~kW}) \mathrm{C}$ Band ( 1 us pulse) & $6.0 \mathrm{dBZ}$ \\
\hline CDV TWT ( $8 \mathrm{~kW}) \mathrm{C}$ Band ( $5 \mu$ s pulse) & $-7.0 \mathrm{dBZ}$ \\
\hline CDV TWT (8kW) C Band (NLFM 30 us pulse) & $-6.0 \mathrm{dBZ}$ \\
\hline CDV TWT (8kW) C Band (NLFM 40 us pulse) & $-9.0 \mathrm{dBZ}$ \\
\hline INM Conventional C Band ( $2 \mu$ s pulse $)$ & $-9.0 \mathrm{dBZ}$ \\
\hline
\end{tabular}

Table 5. Minimum Detectable Signal of Various Radars

\section{Forecast process and system design}

Perhaps the most important consideration in the design of the operational radar processing, visualization and decision-making is the underlying philosophy of the weather service, existing systems and, of course, the capabilities and resources available (Joe et al 2002). In many cases, the warning service requirements are driven not only by the scientific capabilities or the needs but also by the political, societal and economic norms. Often a warning service is an ethical and moral reaction by NHMS's to a damaging event or events and hence it is also a political reaction by governments. This varies considerably from place to place. These requirements are tempered by existing observational infrastructure. Are 
there functioning radars or other data sources? Is there the capacity to design or even adopt a radar processing system? Is there the knowledge and capacity to interpret the data products to make effective warning decisions and issue warnings? And is there a way to reach the end-user in a timely fashion? It should not be forgotten that the end-user must be educated on the meaning of the warning and on how to react appropriately. Is there sufficient budget to develop a warning system? What is risk is acceptable? What level is the moral outrage?

An often overlooked design issue is the organization of the weather service. Warnings are provided for small areas (scale of the weather feature) in order to mitigate the "cry wolf" syndrome to be effective (Barnes et al, 2007; Hammer and Schmidlin, 2002). The critical issue is the capacity to provide the attention to the detail given the totality of the forecast responsibilities. The system design will be quite different if there are many forecast offices and few radars (one to one) compared to few offices and many radars (one office to ten radars as in Canada).

Of course, an overarching issue is the climatology of severe weather which ultimately is the core issue. For many countries, convective weather may occur year round and some only for the summer season. In the latter case, a design question is to determine the use case for the shoulder season where severe weather may occur unexpectedly and the warning service is seasonal.

Severe weather forecasting requires a unique forecasting skill set. In synoptic forecasting (for 12 hours and beyond), the forecaster compares current observations to numerical weather prediction models to evaluate the appropriateness of the model or to develop a conceptual model of the weather for the creation of the public forecast product (Doswell 2004). The product is usually produced on a fixed schedule. In severe weather forecasting, the observations need to be timely; there is urgency in the interpretation and the generation of the warning product. It is a "short fused" situation. These require different personality types and this also drives the design considerations. In order to mitigate the "cry wolf" situation while maintaining high probability of detection, a dedicated and separate warning forecaster function is required to be able to address the immediacy issues of the warning service. These are just some of the design considerations for a radar processing and visualization system and the forecast process for the provision of severe weather warnings. Forecast process refers to all components of the transformation of the data or observations into information used for decision- making and warning service production. It includes both the human and their tools and is often referred to as the man-machine mix. Given all the degrees of freedom in the chain, there are different models of the forecast process.

In the next section, a global survey (necessarily incomplete) is presented that will briefly examine the operational or near-operational systems that have been developed. Many have commonalities and only the underlying unique aspects will be highlighted.

\section{Components of a basic system}

In this section, the basic components or issues of severe weather radar processing/visualization are briefly discussed and a block diagram is provide in Fig. 5 . The benefits of different radar types are discussed elsewhere (WMO, 2008). 


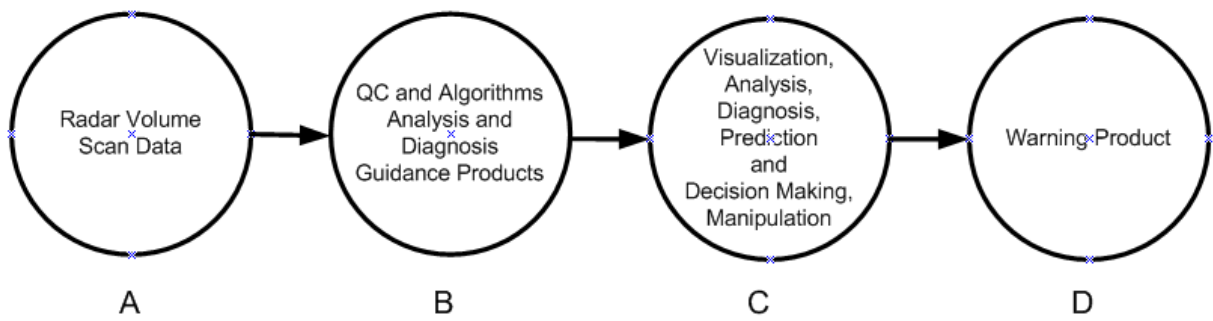

Fig. 5. The flow of the radar data to warning product is much the same in all systems. But the contents of each stage can be different. Except for one system described in this contribution, all the others require human decision-making at stage $\mathrm{C}$ before the warning product is issued to the public. In the case of KONRAD (see section 6.10), the product goes mainly to "sophisticated" users.

\subsection{Data quality}

Radar processing systems need quality controlled data. This can occur in a separate and independent process. In some cases, it is part of the adjustments and corrections that need to be made. Before the severe weather processing occurs (stage B in Fig. 5), it is assumed that the data is free of anomalous propagation, ground clutter and biases in power are adjusted. Second trip echoes and range folded may still be in the Doppler data (Joe 2009; Lakshmanan et al, 2010; Lakshmanan et al, 2011).

In high shear environments the assumption that the radial velocities within a range volume are uniform may not be satisfied (Holleman and Beekhuis 2003; Joe and May 2003). Fig 6ab shows a simulated Doppler velocity spectrum (based on an example in Doviak and Zrnic, 1984) of a tornado contained within a single range volume. The spectrum is bi-modal and the peaks at located at the speed of the radial components of the tornado. Normally it is unimodal and Gaussian in shape. Fig. 6cd show the measured spectrum given two different Nyquist limits. The spectrum is aliased and overlaps with itself. The smaller the Nyquist limit, the greater the overlap. In highly sheared regions, the velocity data is noisy and can be non-sensical. The chapter on quantitative precipitation estimation addresses many of the quality control issues. 


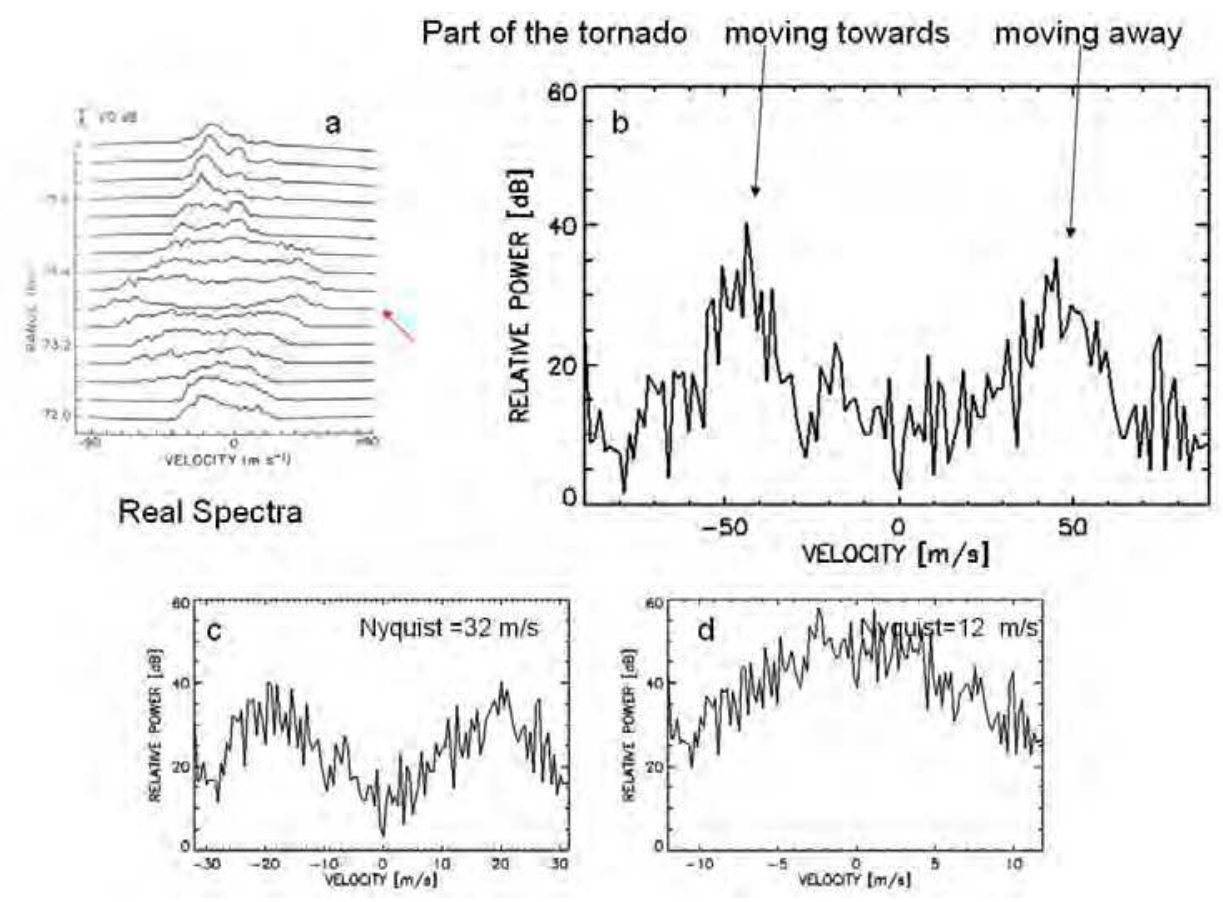

Fig. 6. (a) Doppler velocity spectra at different ranges made with a radar with a very large Nyquist interval. The arrow points to the tornado. The spectrum is bi-model. (b) a simulation of the spectra. (c) and (d) are simulated measured spectra made with different Nyquist intervals. The spectrum overlaps and is aliased. In (c) the spectra is bi-modal still, would produce a radial velocity estimate near zero with a very broad variance. In (d), the mean is still zero, the spectra is uni-modal with a smaller variance.

\section{Global survey}

This section provides a necessarily brief global survey of various convective weather radar processing systems. In fact, there are only a few NHMS' that actually provide a severe weather warning service. The systems are presented in a sequence that approximately matches when they were developed and the reader can follow the progression of the system and philosophical developments.

\subsection{RADAP - II, U.S.A.}

The first radar processing system for severe weather was RADAP-II and it was built in the 1970's (Winston and Ruthi, 1986) and it followed from D/RADEX (Breidenbach et al, 1995; Saffle, 1976) within the National Weather Service. They used VIL (vertically integrated liquid water) and a significant innovation was the introduction of a SWP (Severe Weather Probability) product. They were using probabilistic and uncertainty concepts then! There were many innovations with RADAP-II but its deployment was curtailed due to the development of the Doppler upgrade called the WSR-88D (Crum and Alberty, 1993; Lemon et al, 1977; Wilson 
et al, 1980). Crane (1979) developed the cell identification techniques based on peak detection. These systems left a legacy for the development of the WSR88D algorithms. McGill developed SHARP (Bellon and Austin, 1978) for precipitation nowcasting and developed the crosscorrelation method for echo tracking which is still used today. It did not specifically address severe weather algorithms, which is the focus of this contribution.

\subsection{WSR-88D, U.S.A., WSR-98D, China}

Many of the innovations for the reflectivity-only algorithms of RADAP-II were adopted and significantly enhanced for the WSR88D (Crum and Alberty, 1993; Kitzmiller et al, 1995). Doppler algorithms were developed for mesocyclone and gust front detection (Hermes et al 1993; Uyeda and Zrnic, 1986; Zrnic et al, 1985). Considerable effort has been expended to improve upon these initial efforts. A search of the American Meteorological Society journal publications will illustrate that. Initially, the output from the WSR88D Radar Product Generator was displayed on a dedicated radar-only visualization system called the Principal User Product (PUP) display for the forecaster and later the forecaster workstation called AWIPS was used. This integrated all the data and products that the forecaster needed. WSR88D algorithms were later deployed on the WSR-98D radars made by MetStar and used in China, Romania, India, Korea and other places.

A fundamental question arose as to the role of automated guidance products versus manual interpretation (Andra et al, 2002). It is clear that automated generated products are for guidance and it should not be mistakenly interpreted that warnings were automatically generated and issued without an intervening well trained decision-maker. Initially, there was an extensive radar training program for forecasters, up to 6 weeks for specialists. Clearly, the expectation was that an expert level of training was needed to interpret Doppler radar data for severe weather warnings. This was re-enforced by the work of Pliske et al (1997) who analyzed how to achieve the expected benefits of a modernization program. This resulted in the development of an on-going training program for decision-making at the appropriately named, Warning Decision Training Branch of the National Severe Storms Laboratory. Professionally trained instructors on cognitive principles interactively have the skills to tailor the material to the appropriate knowledge level, abilities and learning styles of the student. It is a model for professional training.

\subsection{TITAN - NCAR}

TITAN (Thunderstorm identification, tracking and nowcasting) was first developed in South Africa and then later at NCAR for support of weather modification programs. Dixon and Weiner (1993) described a simple but brilliant threshold technique for the identification of thunderstorm cell cores. This simplified the peak detection techniques of the Crane (1979) technique as the latter identified many weak cells and challenged the computing power of the day. It also described a methodology for tracking. It could be argued that this is the most widely used system in the world. It is freely available and requires some expertise to implement. It is used extensively in research environments (Lei et al, 2009). It is a stand alone system and integrating it into an operational environment has been done but there are capacity and support issues to consider. For example, it is used at the South African Weather Service. 


\subsection{WDSS-I and II - USA}

WDSS-I was a research analysis tool and made great strides in developing innovative algorithms and concepts. WDSS-I (Eilts et al, 1996) processed single radar data. A particular innovation was the Storm Cell Identification and Tracking algorithm (Johnson et al, 1998) which ranked the storms by severity. This extended the SWP product from RADAP-II. This system is commercially available from Weather Decision Technologies. WDSS-II was an enhanced version of WDSS-I (Lakshmanan et al, 2006). It has a multiradar capability and integrates other data. Fig. 7 shows a chart of the data processing flow and lists the algorithms. A technical innovation is in the handling of radar data in overlap regions. Radar cell identifications (and others such as mesocyclone detection) are first done along each PPI surface to identify 2D cell objects. Then these 2D objects are collated together into a 3D multi-radar object. A five minute window is used to aggregate the data and cells are time shifted to a common moment in time. A service innovation is that this extends the warning service capability to a regional level (more than the domain of single radar). WDSS-II saw the return to the display of more imagery to support experts in their decision-making (Fig. 8).

Fig. 8 shows shear fields and aggregated shear fields. While they were computed as part of the severe weather algorithms internal computations, they were not previously displayed. With the development of fast computers and display capabilities and the realization that expert forecasters can effectively use these products, they became in vogue.

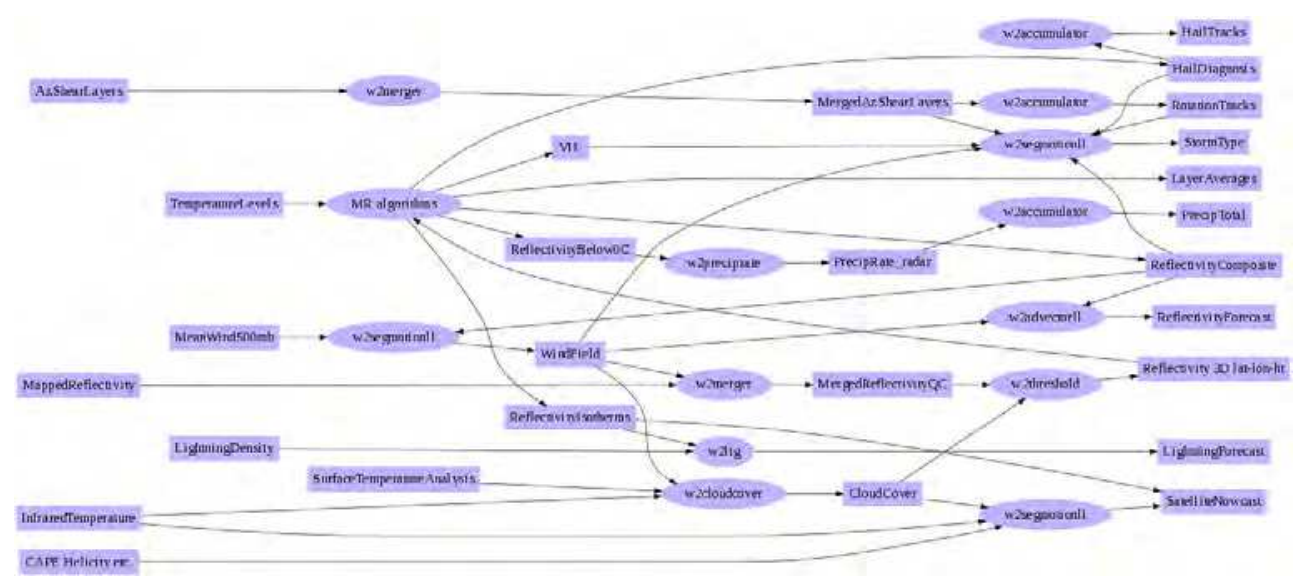

Fig. 7. The data flow of the WDSS-II system. This system integrates "other" data (numerical weather prediction data) including model data into the radar processing. While this is common for QPE applications to help identify the bright band or melting level, this was an innovation in severe weather processing. 

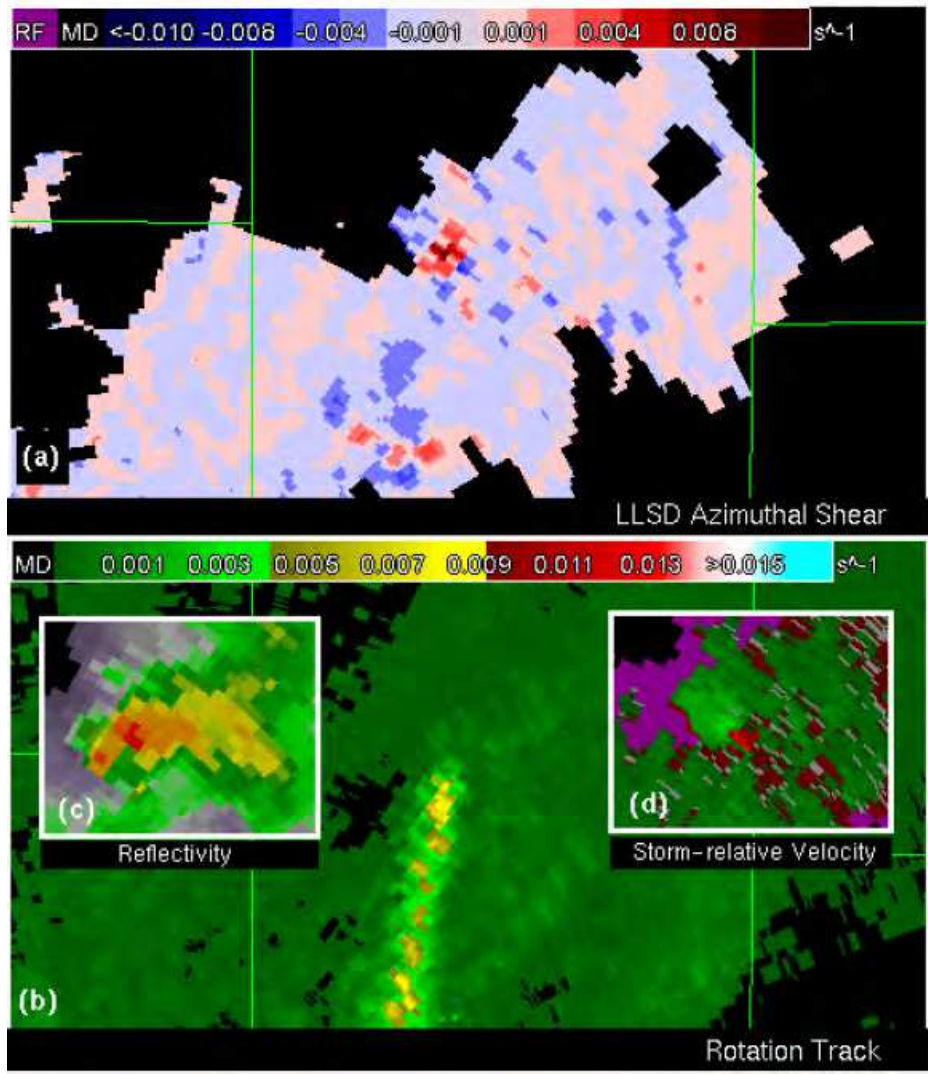

Fig. 8. In this system, there is a trend to go back to basic imagery products such as shear and aggregated shear to aid in the interpretation and utility of the data.

\subsection{CARDS - Canada}

The CARDS (Canadian Radar Decision Support) system was developed as part of the radar upgrade (Joe et al, 2002; Lapczak et al, 1999) and built on the previous concepts. In Canada, a single severe weather forecaster is responsible for the provision of warnings for the area coverage of about ten radars. This is in contrast to other countries, where it is approximately one radar for one forecaster. While this may seem like a work overload situation, there are some interesting side benefits. It has been estimated that in a one radar for one forecaster situation, a forecaster will likely face only one significant event in his career. In the Canadian scenario, a severe weather forecaster will therefore experience ten big events. It can be argued that these experienced forecasters will be better at decision making and will therefore make better warnings (Doswell, 2004). Forecasting is a complex process and it remains to be seen whether this is a true. Given these constraints, the weather service of Canada is arguably the most reliant on automated guidance products. They are critical in aiding the forecaster to diagnose those cells which need detailed interrogation to upgrade from a severe weather warning to a more specific warning. 

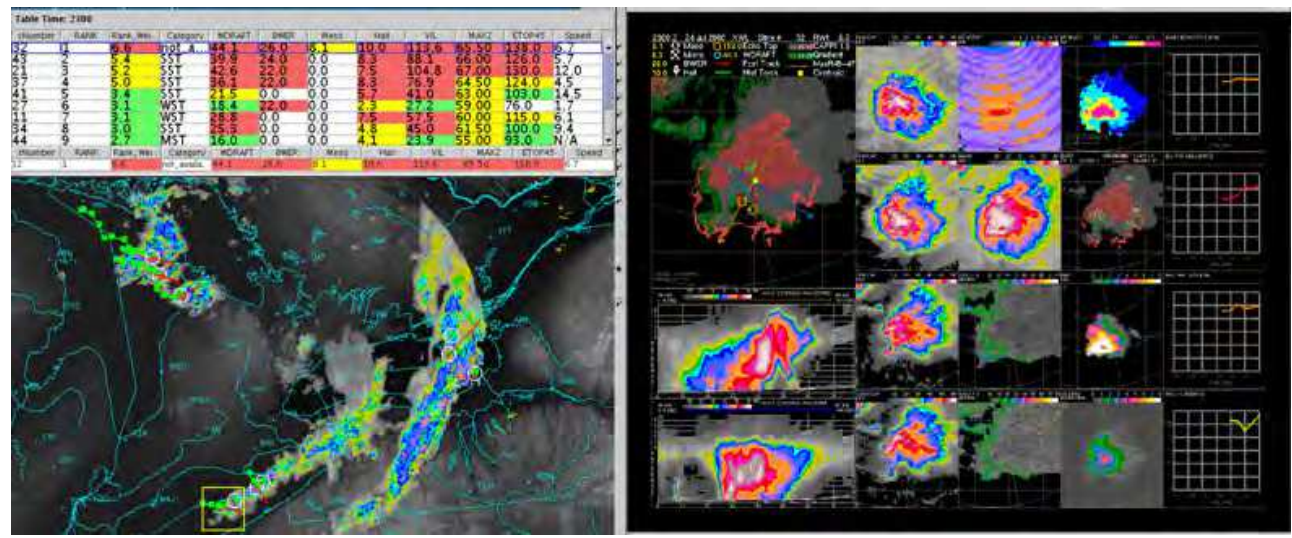

Fig. 9. An example of a CARDS composite, SCIT and cell view. The size of the forecast domain is about $\sim 2000 \mathrm{~km} \times 1600 \mathrm{~km}$. The image shows a zoomed image of the cells, tracks and lightning strikes. Eight Canadian radars and 12 US radars contribute to the image. The composite and the SCIT table products are invoked and displayed at the same time. The forecaster can either drill down to a CELL VIEW via the composite or via the SCIT table. They can also rapidly survey the cells from the SCIT table without invoking the CELL VIEW products. The colour coding indicates the categorical ranking. On the right is an example of a cell view. This shows a variety of images that allows the forecaster to quickly make a decision as to the severity of the storm. The product shows an ensemble product of the algorithms (upper left hand corner, not described), automatically determined cross-sections, four CAPPIs (1.5, 3.0, 7.0, $9.0 \mathrm{~km})$, reflectivity gradient, MAXR, echo top, VIL density, Hail, BWER and $45 \mathrm{dBZ}$ echo top and time graphs.

In an envisioned future exercise for the design of CARDS, it was identified that there was actually no hard requirement for single radar products. One of the main reasons for missed warnings was that the forecaster was so intent on one thunderstorm that they forgot about the others. There was a loss of situational awareness. This happens even with experienced forecasters or analysts and is common in many fields where critical decisions are made. A regional composite that could display and overlay the most popular products (CAPPI, EchoTop, etc) is the main product to maintain situational awareness. Thunderstorms cell locations are identified, ranked, color coded and displayed on the composite and in a table similar to the SCIT table. Selecting the cell of interest in the composite or in the table, the user is able to quickly and rapidly drill down to reveal a cell view product (Fig. 9) that contain all the products that the user would use to interrogate a cell and make decisions. The cell view has a legacy from Chisholm and Renick (1972). The design exercise also identified the critical reliance on automated guidance products.

Another important innovation is that the visualization tool for the image and data products is based on hypertext transfer protocol (http) which means that any computer regardless of operating system can access the full functionality of the radar data. Analyzing breakthroughs in the use of radar, access to the data and the products has been "the" key innovation. Recall the days of radar operators who hand drew radar maps or the facsimile 
machine or the mono or color graphics terminal. Each innovation increased the capacity to deliver better products. In today's technology, every button press or mouse click that is eliminated delivers "a big bang for the buck". This key innovation allowed the data to be effectively used in the Sydney Olympic Command Centre (Joe et al, 2004; Keenan et al, 2004).

Similar to the SCIT of WDSS-I, CARDS implemented a fuzzy logic technique to rank storms. The technique is configurable (see Table 6). It shows the parameters that the users decided to use and the thresholds that they considered as weak, moderate, strong and severe (see also Doswell et al, 2006).

In the overlap region, cells are selected from one radar or the other, unlike WDSS-II. Due to attenuation concerns, lack of experience with the fuzzy logic storm severity technique and that reflectivity (and reflectivity based products) was still the prime parameter for determining storm severity; users selected the cell detection with the maximum reflectivity as the cell for visualization. However, this would likely not be the case anymore as nearest radar or maximum information or maximum severity ranking would be chosen today.

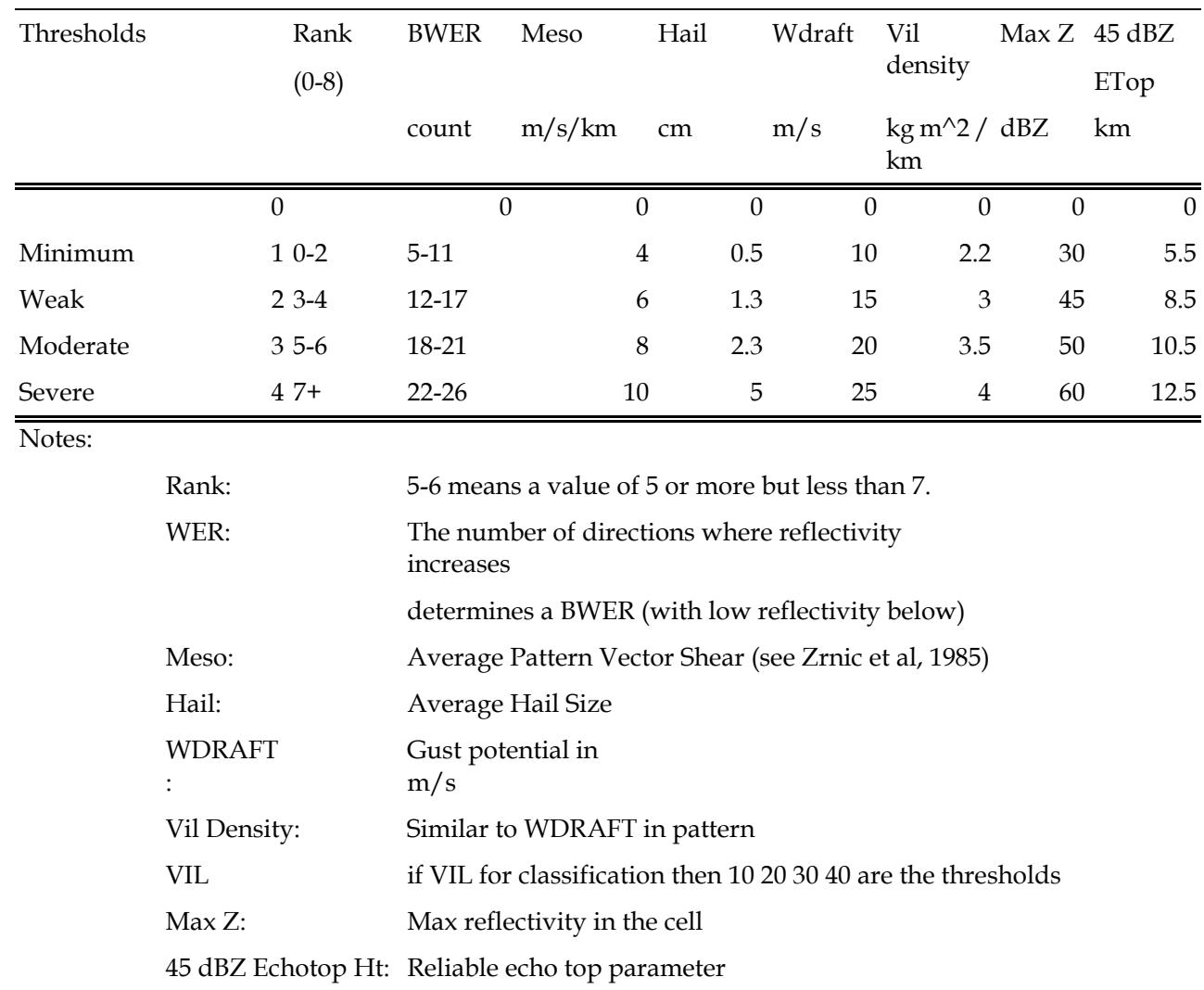

Table 6. Fuzzy Logic Membership Functions for Parameters Used to Rank Storms. 


\subsection{SWIRLS and its variants - Hong Kong, China}

In Hong Kong, lightning strikes and damaging squalls are major threats accompanying thunderstorms. In support of the Thunderstorm Warning operations, SWIRLS (Short-range Warning of Intense Rainstorms in Localized Systems) was developed to track and predict severe weather including rainstorms, cloud-to-ground (CG) lightning, damaging thunderstorm squalls and hail for the general public. The warning decision and message preparation are made by the Observatory's duty forecaster. Once issued, the warning message are disseminated automatically through various channels including radio and television broadcast automatic telephone enquiry system, Internet web page, as well as mobile apps for smart phones and social networking platforms such as Twitter.

An innovation is the DELITE (Detection of cloud Electrification and Lightning based on Isothermal Thunderstorm Echoes) algorithm for lightning warning. It selects radar and other parameters most relevant to the microphysical processes leading up to the electrification of a cumulus cloud (Fig. 10). This includes radar reflectivity at constant temperature levels $\left(0^{\circ} \mathrm{C},-10^{\circ} \mathrm{C}\right.$, and $\left.-20^{\circ} \mathrm{C}\right)$, the thermal profile of the troposphere (from either numerical weather model analysis or the latest available radiosonde data), the echo top height and the vertically integrated liquid (VIL). CG lightning initiation is expected if prescribed thresholds are exceeded.

The above severe weather analyses are performed on a cell basis and the threat areas are identified as elliptical cells in the corresponding interest fields with values greater than or equal to prescribed thresholds. For example, the detailed cell identification technique follows the GTrack algorithm of SWIRLS. For lightning and downburst, the interest fields are 3-km CAPPI and 0-5 km VIL respectively. The thresholds are $25 \mathrm{dBZ}$ and $5 \mathrm{~mm}$ respectively.

MOVA (Multi-scale Optical flow by Variational Analysis) is a gridded echo-motion field that is derived from consecutive radar reflectivity fields by solving an optical-flow equation with a smoothness constraint. To capture multi-scale echo motions, the optical-flow equation is solved iteratively for a cascade of grids from coarse to fine resolutions (about 512 to $3 \mathrm{~km}$ ).
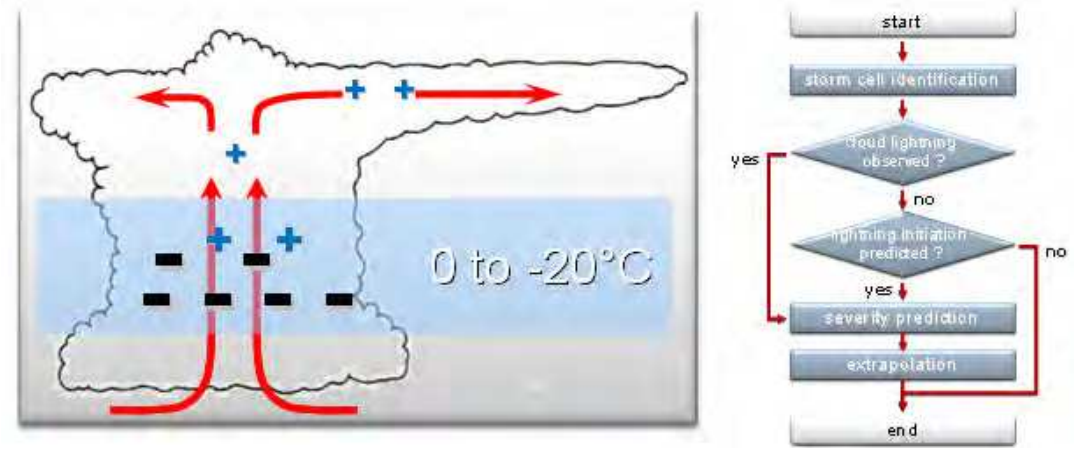

Fig. 10. (a) Conceptual model of CG lightning. The main source of electric charges is assumed to be located in the mixed-phase layer between 0 and $-20^{\circ} \mathrm{C}$. Prior to electrification, the updraft is expected to separate the charge carriers vertically. Negative charge carriers (i.e. graupel) are expected to reside mainly in the mixed-phase layer. The updraft pumps super-cooled rain water into this layer and wet the carriers. (b) Flow chart of the logic of the algorithm. 
SWIRLS updates and outputs nowcast products at 6-minute intervals. For severe thunderstorms, the major results are visualized as an image product called the Severe Weather Map on its client workstation in the forecasting office, as well as a web page named SPIDASS (SWIRLS Panel for Integrated Display of Alerts on Severe Storms) dedicated for severe weather alerts (Fig. 11).
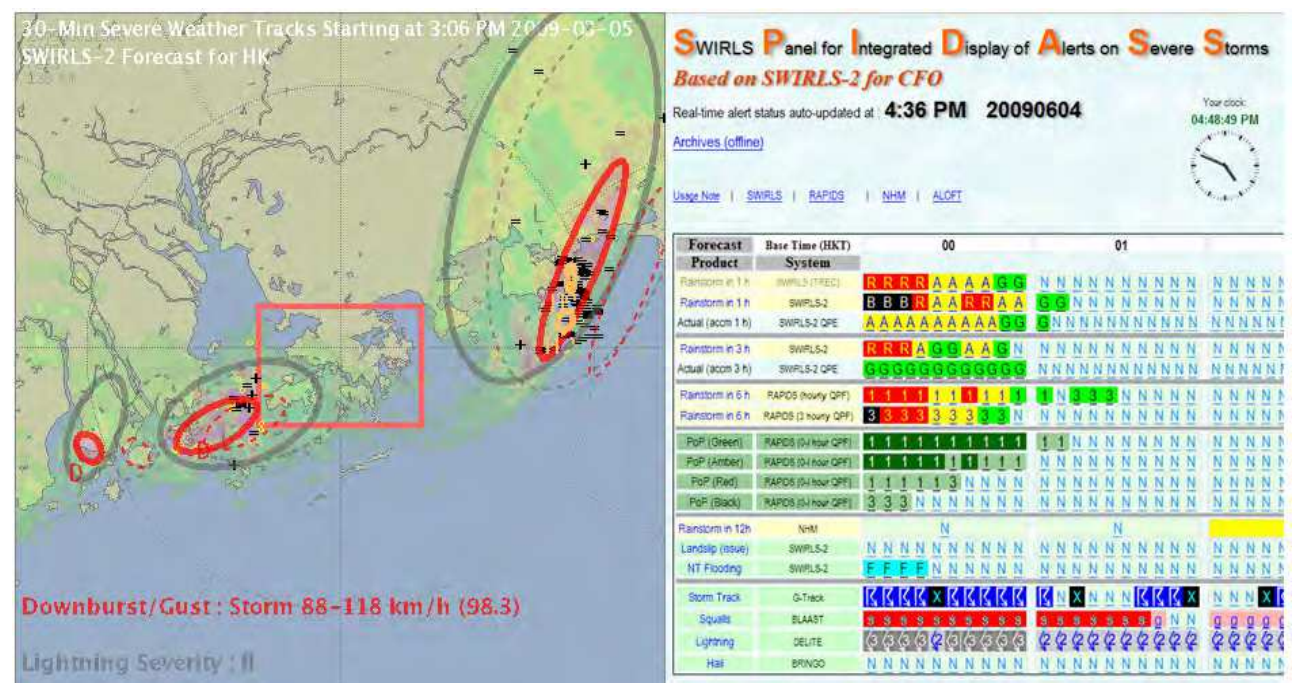

Fig. 11. (a) shows an example of the Severe Weather Map. Textual alerts with quantitative details were printed at the bottom. (b) , the main panel of SPIDASS web page provides a compact view of all alerts arranged in rows and colour-coded for different severity levels.

The Hong Kong Observatory has also developed separate multi-sensor thunderstorm nowcasting systems for the aviation community and the public utilities services (Li, 2009). A lightning nowcasting system, named the Airport Thunderstorm and Lightning Alerting System (ATLAS), covers the Hong Kong International Airport (HKIA). It combines rapidly updated CG lightning strike information, radar reflectivity and TREC wind information to nowcast lightning strikes using a modified Semi-Lagrangian advection scheme. Depending on the predicted distance from HKIA, ATLAS will automatically generate RED $(1 \mathrm{~km})$ or AMBER $(5 \mathrm{~km})$ alerts.

ATLAS is equipped with two ensemble algorithms, to take into account the possible rapid development nature of lightning (transient and sporadic). The Weighted Ensemble (WE) algorithm sums all available 12-minute CG forecasts with decreasing weight with time. If the sum exceeds an optimized threshold, alerts are created. WE has proved to be effective for alerting persistent and wide-spread thunderstorms. The Time Lagged Ensemble (TLE) algorithm sums the 1-minute forecasts valid at the same time from the twelve 1-minute forecasts provided in the past 12 minutes with decreasing weight over time. TLE is proved to be more skilful in predicting rapidly developing, small or wide-spread thunderstorms than WE. Figure 12 shows a snapshot of the ATLAS product. 


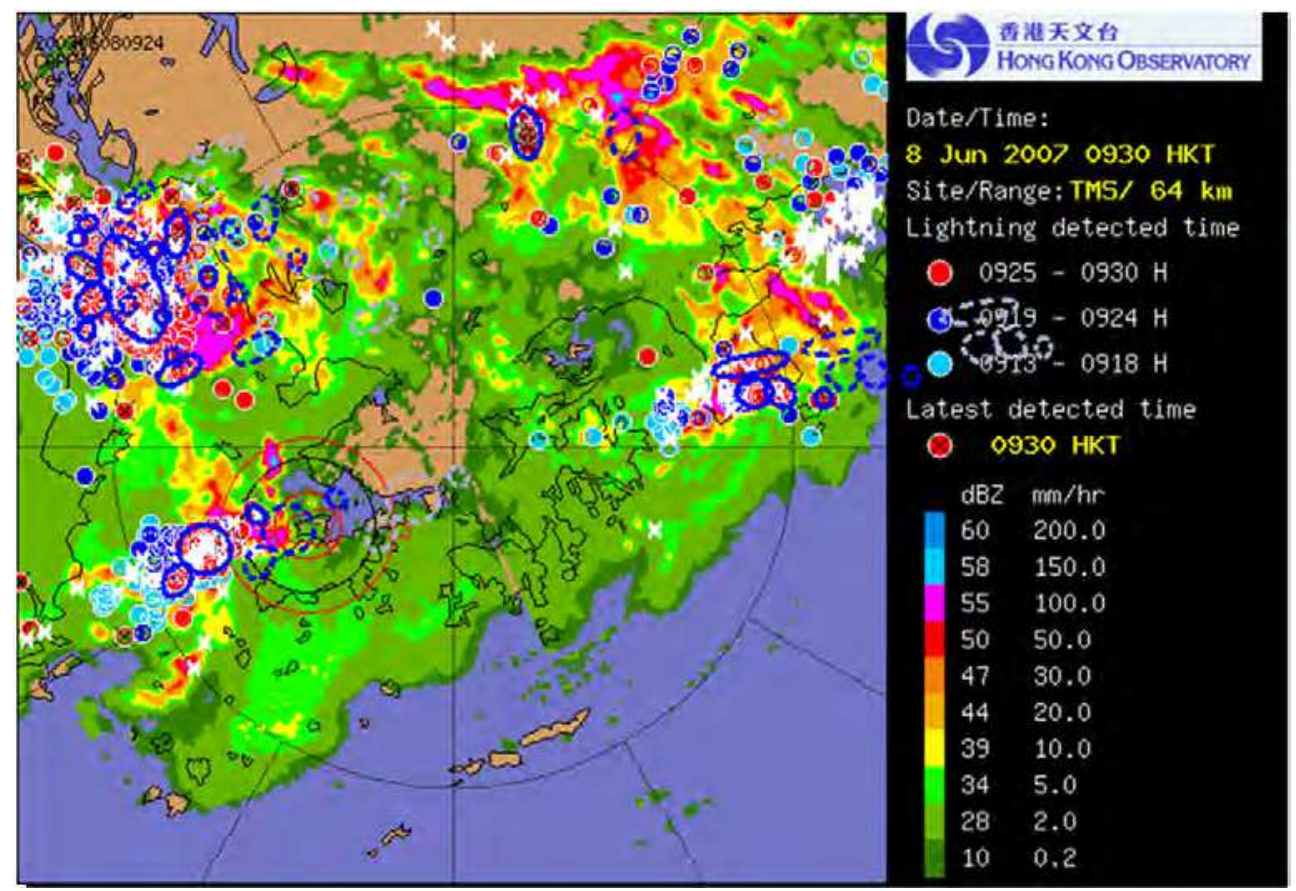

Fig. 12. A snapshot of ATLAS webpage. The image shows the actual position of the CGs (ellipses with solid line), the predicted CGs (ellipses with dashed line), the 12-minute forecast in blue and the 30-minute forecast in grey.

The Aviation Thunderstorm Nowcasting System (ATNS) has been developed to predict the movement of thunderstorms to help local Air Traffic Management to better manage the flight traffic over the Hong Kong Flight Information Region for the next few hours (Li and Wong, 2010). A blending approach is adopted to extend the forecast range and to capture the development and dissipation of thunderstorms. The NWP model used is a high resolution non-hydrostatic model with horizontal resolution of $5 \mathrm{~km}$ (Li et al. 2005; Wong et al. 2009). Volume radar reflectivity data are ingested into the model via the LAPS data assimilation system (Albers et al. 1996) and radar Doppler radial wind and 3D radar winds are assimilated via the JNoVA-3DVAR data assimilation system (Honda et al. 2005) to improve the initial moisture field and wind fields, respectively.

The blending algorithm is as follows: (i) SWIRLS radar forecast reflectivity is converted into surface precipitation using a dynamic reflectivity-rainfall (Z-R) relation; (ii) precipitation forecasts are extracted from the NHM; and (iii) then they are blended. The latter blending process involves: (i) Phase correction where a variational technique minimizes the root mean square error of the forecast rainfall field from a previous model run (usually initialized at 1-2 hours before) and the actual radar-raingauge derived precipitation distribution (Wong et al. 2009). (ii) Calibration of the QPF rainfall intensities is based on the observed radar-based quantitative precipitation estimate (QPE), and (iii) blending of calibrated model QPF with the radar nowcast out to 6 hours where the weighting is biased 
to the nowcasts in the early stages and towards the model at the longer lead times. Figure 13 shows the comparison between the effects of ATNS using SWIRLS simple extrapolation (1-6 hours forecasts) and ATNS using SWIRLS-NHM blended forecasts for the case of 4 Jun 2009 (1-6 hour forecasts). The simple TREC extrapolation (left column) overpredicts the rainfall intensities in this case at long lead times (6 hours).



Fig. 13. An example showing the comparison between the effects of SWIRLS simple extrapolation and blending of SWIRLS and NHM rainfall. Figures from top to bottom are 1$\mathrm{hr}, 2-\mathrm{hr}$ and $6 \mathrm{hr}$ simple extrapolation (left column), AANS blended precipitation (middle column) forecasts and the radar-based QPE (different scale). 


\subsection{SIGOONS - France}

Significant Weather Object Oriented Nowcast System (SIGOONS) is a component of the Synergie workstation (Brovelli et al, 2005). Thunderstorm cells are identified using the RDT (Rapidly Developing Thunderstorms) technique by Hering et al (2005) and are represented as objects. This database is updated every five minutes and is automatically quality controlled against other observational data. The objects may have deterministic and probabilistic attributes and have a time dimension - they can grow and decay. Products are automatically generated and tailored according to pre-defined customer requirements. Discrepancies are brought to the attention of the forecaster who can select persistence over linear extrapolation nowcasts. The forecaster can take additional initiative. The attributes of the weather objects can be manipulated and altered by forecasters.

\subsection{THESPA and TIFS, Australia}

Within the Bureau of Meteorology, forecasters use RAPIC to interactively interrogate the data. The innovation is the radar data is loaded on the graphics memory of the client computer and extremely rapid response of the display is achieved. To avoid dual-PRF dealiasing errors, only single PRF data is used resulting in a Nyquist interval of $16 \mathrm{~m} / \mathrm{s}$. This implies considerable forecaster training is required to interpret highly aliased Doppler data.

Thunderstorm Strike Probability (THESPA, Dance et al, 2010) generates probabilistic nowcasts. Using the historical statistics of the nowcast position errors as a function of lead time and detected storm properties, storm motion is modeled as a bivariate Gaussian distribution on storm speed and direction. For a given geographical point, the strike probability from all possible thunderstorms is computed for the forecast period (Fig. 14).

The algorithm is embedded in the Thunderstorm Interactive Forecast System (TIFS, Bally 2004). The Beijing Olympics provided an opportunity to explore and prototype new nowcasting techniques (Wang et al, 2010). TIFS was modified to ingest the storm locations and tracks from the CARDS, SWIRLS, WDSS and TITAN to create a poor man's ensemble. From each of the storms and tracks, THESPA was used to compute a consensus or ensemble strike probability (Fig. 14b). A warning product would be automatically generated. The analyst (B08 Forecast Demonstration Project team member) would evaluate the product and determine if intervention was needed. The analyst could then use the graphical interface and add, delete or modify cells or tracks. The analyst could view and modify any of the ensemble members and the strike probability display would update. Accepting the change would regenerate the automated warning product, be disseminated and overwriting the fully automated product.

\subsection{NoCAWS - SMB}

The Shanghai Meteorological Bureau's NoCAWS system was one of the nowcast systems used for the World Expo on Nowcasting Services (WENS) component of the Multi-hazard Early Warning Service project (MHEWS). It integrates observations, mesoscale models and nowcasts to host data displays; analysis tools, severe weather alerting tools to generate automatic forecasts and warning for forecasters. It covers the scales from outlooks to warnings. An innovative feature is lightning forecasts. COTREC winds are used to nowcast cell motions. Advection and statistical relationships between lightning and reflectivity are used to nowcast lightning (Fig. 15) 

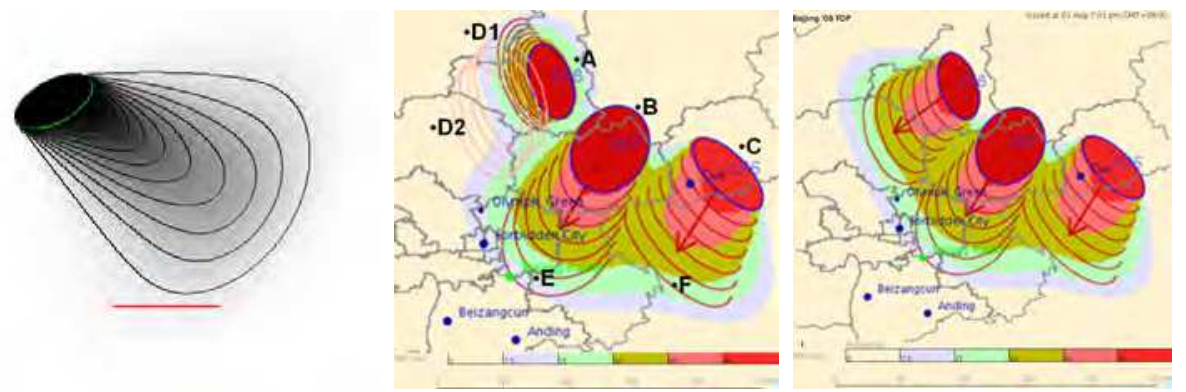

Fig. 14. (a) The detected thunderstorm is the ellipse oriented south-west to north-east. A motion to the south east is shown. The contours and shading show the probability that the thunderstorm will advect or propagate into those locations. The probabilities were verified for a season of storms around Sydney and Beijing, with excellent reliability, with a Brier skill score of between 0.36 and 0.44 with respect to an advected threat area forecast. (b) An example of a prototype TIFS strike probability product. Three cells are identified as A, B and $C$ and represented as ellipses. The tracks of $B$ and $C$ are indicted by the partial ellipses and the colours indicate the strike probability, marked as E and F and appear consistent. The track for cell A is marked as D1 and appears anomalous. D2 is the track that the analyst has modified to produce the final strike probability map (c).

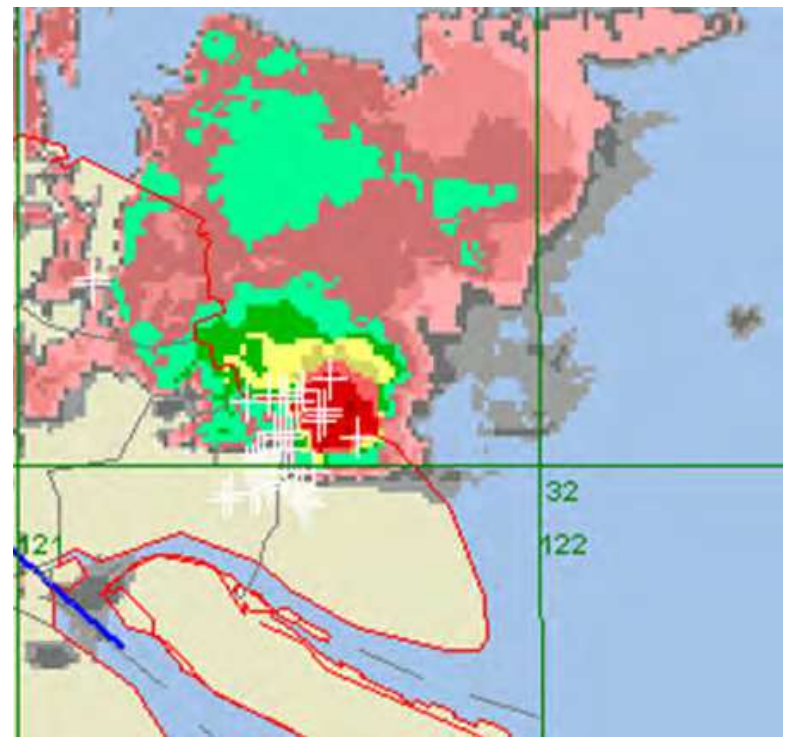

Fig. 15. This figure shows a nowcast of the reflectivity and lightning from NoCAWS. The plus signs are nowcasts of lightning strikes. 


\subsection{KONRAD/NinJo/NowCastMIX - DWD}

There are several tools in the German Weather Service and include KONRAD (Lang et al, 2001), Mesocyclone detection (Hengstebeck et al, 2011), AutoWARN, EPM (editing, prediction, monitoring), Cellviews (Joe et al, 2003). All of these are integrated into the Ninjo system (Koppert et al, 2004). KONRAD was developed as a research prototype and uses a variable elevation angle PPI reflectivity product for the identification and warning potential of cells. The 10 minute volume scan product is used for further classification. The cells are displayed as abstractions and only a $>28 \mathrm{dBZ}$ contour is displayed in the end user product (Fig. 16). Of all the systems discussed, it is the only truly automated system where the products go directly out to the end-user without human oversight. However, it targets sophisticated end-users such as emergency authorities, county administrators, fire departments and the military and not the public. One could argue that these are guidance products for external versus internal decision-makers for planning but not warning service. So the "cry wolf" syndrome is not a significant issue. This does demonstrate the potential use of fully authomated products.

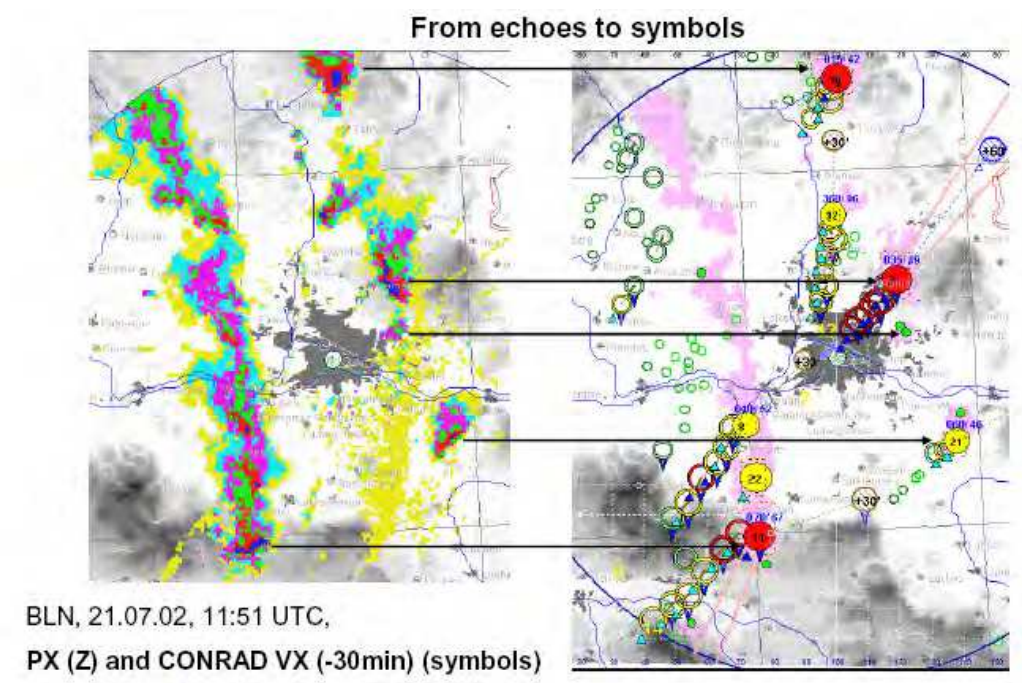

Fig. 16. An example of the abstraction from reflectivity to symbolic representation of thunderstorms from the KONRAD system. It is the only system described in the contribution that is totally automated. It is directed to "sophisticated users" for planning purposes.

The AutoWARN system in NinJo integrates various meteorological data and products in a warning decision support process, generating real-time warning proposals for assessment and possible modification by the duty forecasters. These warnings finally issued by the forecaster are then exported to a system generating textual and graphical warning products for dissemination to customers. On very short, nowcasting timescales, several systems are continuously monitored. These include the radar-based storm-cell identification and tracking methods, KONRAD and CellMOS; 3D radar volume scans yielding vertically integrated liquid water (VIL) composites; precise lightning strike locations; the precipitation prediction system, RadVOR-OP as well as synoptic reports and the latest high resolution numerical analysis and forecast data. 




Fig. 17. An example of NowcastMix. It combines and merges the output from several nowcasting systems into a hazard map.

Since there are several nowcasting systems avaliable, NowCastMIX processes these available nowcast products together in an integrated grid-based analysis, providing a generic, optimal warning solution with a 5-minute update cycle. The products are combined using a fuzzy logic approach (James et al 2011). The method includes estimates for the storm cell motion by combining raw cell tracking inputs from the KONRAD and CellMOS systems with vector fields derived from comparing consecutive radar images. Finally, the resulting gridded warning fields are spatially filtered to provide regionallyoptimized warning levels for differing thunderstorm severities for forecasters. NowCastMIX delivers a synthesis of the various nowcasting and forecast model system inputs to provide consolidated sets of most-probable short-term forecasts (Fig. 17).

\subsection{Japan - JMA}

Japan Meteorological Agency initiated their hazardous wind warning program in 2007. A hazardous-wind-possibility-index is calculated based on the NWP prediction of wind and radar reflectivity exceeding a threshold. An innovation is the use of a template matching technique for the detection of mesocyclones. Rankine vortex and divergence flow field templates of different intensity and spatial scale are generated and matched to the radial velocity field. This is done every five minutes. Detections on two consecutive time steps are required as a quality controlled metric. Then the two estimates are combined every ten minutes to estimate a hazardous wind potential. Nowcasting is based on a motion analysis. Different thresholds are statistically established and the success ratio (1-FAR) and the probability of detection (POD) are used to categorize the hazard level (Table 7). If level 2 is exceeded (see Fig. 18), then it alerts a forecaster to issue Hazardous Wind Watch. A forecaster may ignore the level 2 information, when: (i) the storm is near the boundary of a warning area and it will be out before the time of warning or (ii) the quality of radar data seems poor (e.g. AP or sea clutter). A forecaster can issue a warning at level 1 when (i) reliable report of a tornado/tornadoes and/or and (ii) strong gust (say, greater than $30 \mathrm{~m} / \mathrm{s}$ ) caused by a convective cloud. 


\begin{tabular}{cl}
\hline Warning Level & Criteria \\
\hline \hline 2 & Success Ratio $=1-\mathrm{FAR}=5-10 \%$ with POD $=20-30 \%$ \\
1 & 1-FAR $=1-5 \%$ and POD $=60-70 \%$ \\
\hline \hline
\end{tabular}

Table 7. Hazardous Criteria Level

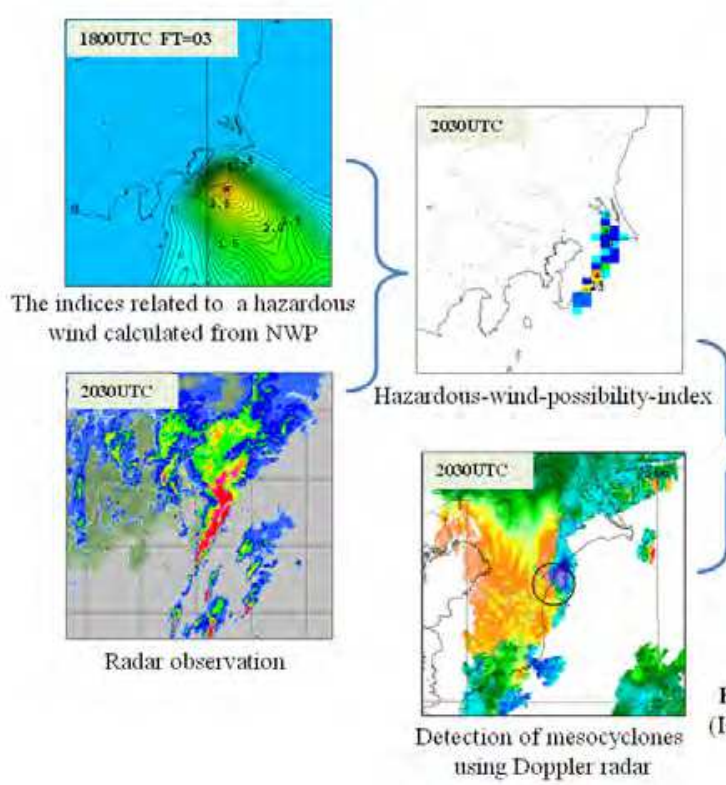

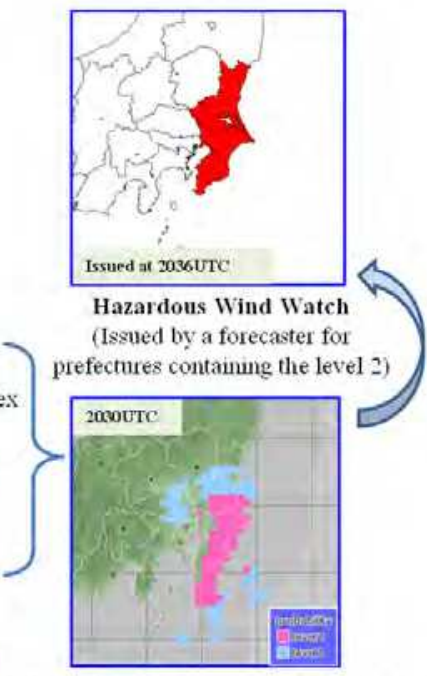

Hazardous Wind Potential Nowcast (Issued every 10 mintes automatically)

Fig. 18. The processing steps for hazardous wind potential at JMA. It is typical of current systems where mesoscale NWP predictions are assumed to be good enough to match with the observations.

\subsection{SWAN - CHINA/CMA}

In 2008, the China Meteorological Administration (CMA) launched a campaign on the development of its first version of integrated nowcasting system SWAN (Severe Weather Analysis and Nowcast system). This system aims at providing an integrated, state-of-the-art and timely severe weather nowcast platform for operational forecasters at all levels over China. SWAN ingests data from China's new generation Doppler radars (both S-band and C-band), automatic weather station, satellite, and mesoscale numerical weather prediction model. It offers a tool for severe weather monitoring, analysis, nowcasting and warnings such as flashing a real-time alert, driving next algorithm processes and sending a warning via SMS, etc.

The server application includes several modules, such as providing log files for monitoring system behavior, configuring network environment, setting data acquisition parameters, performing quality control for radar data and AWS data, generating 3D radar reflectivity mosaic, running algorithm for nowcast products, analyzing observation data and providing message for alerting the forecasters. 
The client refreshes real-time observations cycled in 5 min from radars and AWS (automatic weather stations) and provides real-time alerts (sounding, flashing) for indication of severe weather events (meeting certain thresholds such as wind speeds or rainfall amounts). It also provides an interactive tool for preparing, editing and issuing Nowcast and warning for severe weathers

Based on quality control, a regional 3D reflectivity mosaic is produced by trying to fill the gaps that are generated by terrain blockage or AP. Products such as vertically integrated liquid (VIL), echo top (ET) and COTREC winds are then derived. QPE algorithm involves extraction of convective echoes from stratiform echoes by texture and horizontal gradient properties. Different Z-R relations are used for convective rain and stratiform rain. COTREC (continuous tracking radar echo by correlation) vectors are echo motion vectors that are derived from moving radar reflectivity patterns through grid-to-grid cross-correlation and then adjusted by a horizontal non-divergence constraint for hourly nowcasts of rainfall (Li et al, 1995). This is blended with mesoscale numerical prediction model output for 2-3 hour nowcasts.

SWAN provides real time verifications for storm tracking and reflectivity nowcasts. Storm track errors are shown as distance differences between observed storm tracks and predicted storm tracks (1h). Observed radar reflectivity are also verified against extrapolated forecasted reflectivity.

Severe weather warnings can be prepared and issued through SWAN by graphical interface by circling an area on the screen, clicking an icon and doing some minor wording (Fig. 19). A web-based version of SWAN has been developed and deployed in Guangdong Meteorological Bureau.

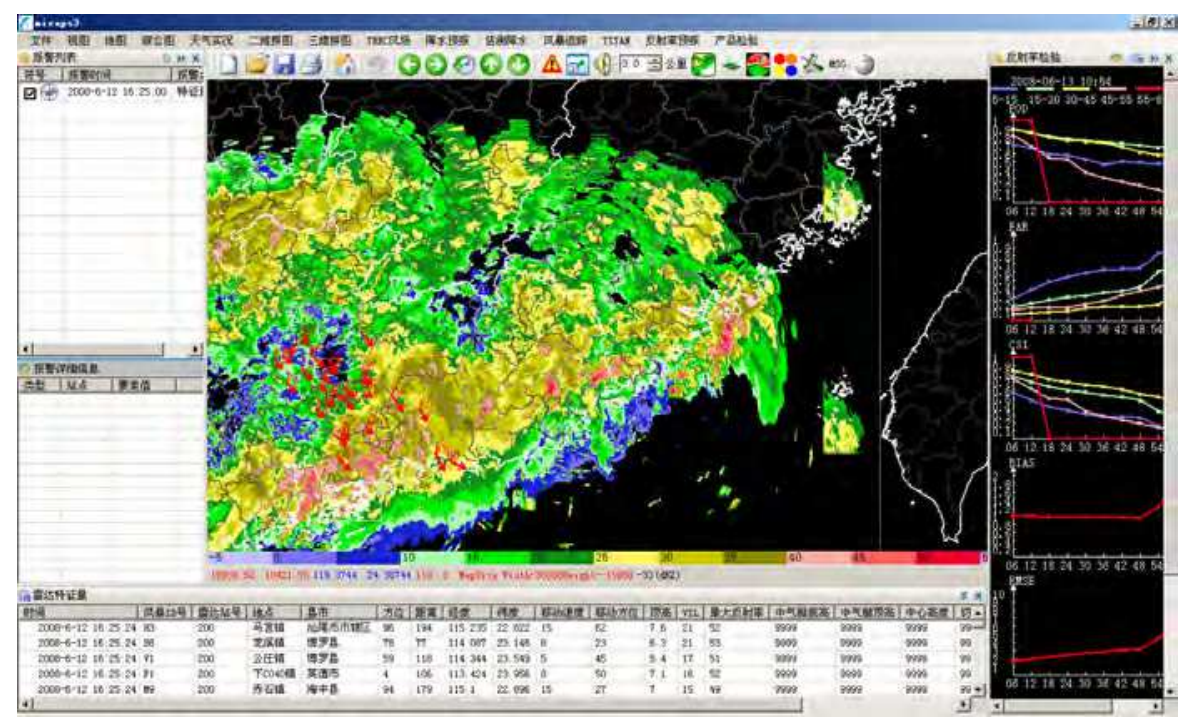

Fig. 19. A SWAN display showing cells/tracks (main screen), SCIT (bottom) and time histories of critical parameters (right). There are similarities with WDSS, NinJo and CARDS displays. 


\section{Conclusion}

The objective of this contribution was to provide a broad overview of the use of radar and radar networks for the provision of severe weather warnings and to very briefly describe historical legacies and current practice. The target audience are those NHMS' who might be contemplating developing or enhancing such a service. Weather radar clearly plays a central role in this application. Not discussed are important applications such as nowcasting precipitation, quantitiative precipitation estimation, wind retrieval, data assimilation for numerical weather prediction, etc. It also does not address the convective initiation aspects (Roberts et al, 2006; Sun et al, 1991; Sun and Crook, 1994). For a reliable warning service, design, infrastructure (reliable power and telecommunications), support and maintenance are critical and were not discussed in this contribution. These are major considerations but out of scope for this contribution.

The level and nature of the service will be determined by both meteorological and nonmeteorological factors. The prevalence of severe weather, climatology and a defining event determine the impact, the exposure and the opportunity to develop a warning service. Socio-economic factors, risk persona, as well as the organizational structure, are particularly important in the design and expectations for the radar processing, visualization and dissemination systems. This contribution provided a short global survey of radar based systems to illustrate the commonality but also the differences in implementation. One solution does not fit all. Underlying these systems is the forecast process and it is emphasized that they all rely on human expertise in the decision-making process and so the human-machince mix is a critical item. This will drive the expertise and therefore the training requirements for the severe weather analyst.

This contribution highlighted the use of automation in the production of guidance products. Some systems rely on very little automation and totally rely on manual interpretation. All systems, except one, default to this mode. One of most highly automated systems is CARDS (Canada). Automation is necessary because of the need for look at details for warning preparation purposes while maintaining situational awareness in the situation where one forecaster is responsible for about ten radars. It processes radar data for identifying and ranking thunderstorm cells and features. It also creates highly processed image products to streamline and to guide the decision-making process. It still relies on human decisionmaking for the final preparation of the warning. KONRAD is the only system that produces totally automated products. However, it could be argued that these products are directed to "sophisticated users" for their specific planning and decision-making purposes and not warning purposes.

Given the limited space and time, all radar processing systems were inadequately described. There is room for improvement in describing all aspects of the processing chain from better algorithms (e.g. hail, hook echoes; Lemon, 1998; Wang et al, 2011) to advanced concepts where thermodynamic diagnostic fields, useful for understanding, are retrieved (Sun et al, 1991; Sun and Crook, 1994). Through the description of specific innovative aspects of individual systems, and since there are commonalities amongst them, the intent was to provide the reader with an overview of the capabilities of all the systems. There is fine work being done elsewhere that is not represented; to name a few, Italy, Switzerland and Finland. Another glaring oversight is the lack of description of systems by manufacturers. Some even 
offer the possibility for the NHMS to add their own specialized products into their systems. Many of the countries mentioned above in fact use a combination of products from their own systems and those of the manufacturers. Information is readily available in trade shows or on their web sites. The ideal requirement is a seamless, user-friendly integrated visualization, decision-making and production system to cover all scales (the seamless prediction concept) and this is the trend in many NHMS' for all data, products and so radar only processing or visualization systems are an interim step towards this and requires investment, resources, time and effort to achieve. NinJo and AWIPS (not described here) provides an example of how radar is expected to be integrated into a comprehensive forecast analysis, diagnosis, prognosis and production tool.

The purpose of this contribution was to illustrate the issues faced by NHMS's. There is a push to use meteorological technology as much as possible and to automate as much as possible. Computing technology is still a limiting factor - computers, telecommunications and data/product storage are all continuing issues that can always be faster and bigger. If there is the time, the resources and the expertise, manual interpretation of basic radar products is still the best way to provide severe weather warning services and to optimally utilize the considerable capabilities of the forecasters. However, tools are needed to streamline and accelerate the process but this is highly dependent on organizational factors. Automated products introduce another level of complexity and knowledge requirement. They can be black boxes that bewilder the user. However, creating black boxes without diagnostic capabilities, providing poor tools and denying access to basic products and information, is self-defeating. It is a sure way of making smart people (appear) "dumb". The algorithms aren't perfect given the need for high POD. They never will be and they can be better and substantial work on data quality, feature detection and prediction are needed. The systems described exhibit the great efforts and resources are expended to do this. Saving a single button click or a mouse movement can make the difference between a bad and a good system. This is difficult to describe as a requirement and prototyping and demonstration projects are the only way to appreciate this.

While reliable weather radars and expertise play a central role in the warning process, this is still a challenge for many countries. Satellite and lightning systems are now available that have minimal support requirements. Stand alone applications for severe weather can and are being developed for these system. In the absence of radars, there is no question that they will provide benefits but their efficacy, the forecast process and the service level for severe weather warnings need to be demonstrated. No doubt that they should also enhance existing systems that rely on weather radar networks. This is occurring but beyond the scope of this contribution. No convective scale warning service has been soley developed without radar and so this is a new area to investigate. Understanding the technology, interpretation of the data and the products will require more development, enhanced expertise, demonstration and decision-making skills.

For the convective weather problem, dual-polarization radar will have benefits in data quality, hail detection and rainfall estimation but this is again beyond the scope of this contribution (Frame et al, 2009). Earth curvature and beam propagation preclude low level detection and so many of the hazardous phenomena are not actually measured beyond a few tens of kilometer from the radar site and must therefore be inferred from measurements aloft. The CASA (Cooperative Adapting and Sensing of the Atmosphere) is a network of $\mathrm{X}$ 
Band radars that address this issue but it is in early-transitional development (McLaughlin et al, 2009; Ruzanski et al, 2011). It also addresses the issue of rapid or adapting scan strategies (Heinselman et al, 2008) which is being investigated now but beyond the scope of this contribution. In any case, with increasing computing power, telecommunications, additional observations and new technology, these are exciting times.

\section{References}

AMS, 2001: Expectations Concerning Media Performance during Severe Weather Emergencies (Adopted by the AMS Council 14 January 2001), Bulletin of the American Meteorological Society, 2001: Volume 82, Issue 4 705-70.

Albers S., J. McGinley, D. Birkenheuer, and J. Smart 1996: The Local Analysis and Prediction System (LAPS): Analyses of clouds, precipitation, and temperature, Wea. Forecasting, 11, 273-287.

Andra Jr., D. L., E. M. Quoetone, W. F. Bunting, 2002: Warning Decision Making: The Relative Roles of Conceptual Models, Technology, Strategy, and Forecaster Expertise on 3 May 1999, Weather and Forecasting, Volume 17, Issue 3 (June 2002) 559-566.

Bally, J., 2004: The Thunderstorm Interactive Forecast System: Turning Automated Thunderstorm Tracks into Severe Weather Warnings, Weather and Forecasting, Volume 19, Issue 1 (February 2004) 64-7.

Barnes, L. R., E. C. Gruntfest, M. H. Hayden, D. M. Schultz, C. Benight, 2007: False Alarms and Close Calls: A Conceptual Model of Warning Accuracy, Weather and Forecasting, Volume 22, Issue 5 (October 2007) 1140-114.

Baumgart, L. A., E. J. Bass, B. Philips, K. Kloesel, 2008: Emergency Management Decision Making during Severe Weather, Weather and Forecasting, Volume 23, Issue 6 (December 2008) 1268-127.

Bech, J., Vilaclara E., Pineda, N., Rigo, T., Lopez, J., O’Hora, F., Lorente, J., Sempere, D., Fabregas F.X., 2004: The weather radar network of the Catalan meteorological service: description and applications, ERAD, Visby, Sweden, 416-420.

Bellon, A. and G. L. Austin, 1978: The Evaluation of Two Years of Real-Time Operation of a Short-Term Precipitation Forecasting Procedure (SHARP), Journal of Applied Meteorology, Volume 17, Issue 12, 1778-1787.

Bieringer, P., P. S. Ray, 1996: Comparison of Tornado Warning Lead Times with and without NEXRAD Doppler Radar, Weather and Forecasting, Volume 11, Issue 1 (March 1996) 47-5.

Black, A. W., W. S. Ashley, 2011: The Relationship between Tornadic and Nontornadic Convective Wind Fatalities and Warnings, Weather, Climate, and Society, Volume 3, Issue 1 (January 2011) 31-4.

Branick, M. L., C. A. Doswell III, 1992: Polarity, An Observation of the Relationship between Supercell Structure and Lightning Ground-Strike, Weather and Forecasting, Volume 7, Issue 1) 143-14.

Breidenbach, J. P., D. H. Kitzmiller, W. E. McGovern, R. E. Saffle, 1995: The Use of Volumetric Radar Reflectivity Predictors in the Development of a SecondGeneration Severe Weather Potential Algorithm, Weather and Forecasting, Volume 10, Issue 2 (June 1995) 369-37. 
Brooks, H. E., C. A. Doswell III, J. Cooper, 1994: On the Environments of Tornadic and Nontornadic Mesocyclones, Weather and Forecasting, Volume 9, Issue 4 (December 1994) 606-61.

Brooks, H. E., C. A. Doswell III, L. J. Wicker, 1993: STORMTIPE: A Forecasting Experiment Using a Three-Dimensional Cloud Model, Weather and Forecasting, Volume 8, Issue 3 (September 1993) 352-36.

Brooks, H. E., C. A. Doswell III, R. B. Wilhelmson, 1994: The Role of Midtropospheric Winds in the Evolution and Maintenance of Low-Level Mesocyclones, Monthly Weather Review, Volume 122, Issue 1 (January 1994) 126-13.

Brovelli, P., S. Sénési, E. Arbogast, P. Cau, S. Cazabat, M. Bouzom, J. Reynaud, 2005: Nowcasting thunderstoms with SIGOONS. A significant weather object oriented nowcasting system, Météo-France, Toulouse, France, WSN05

Brown, R. A., J. M. Janish, V. T. Wood, 2000: Impact of WSR-88D Scanning Strategies on Severe Storm Algorithms, Weather and Forecasting, Volume 15, Issue 1 (February 2000) 90-10.

Brunner, J. C., S. A. Ackerman, A. S. Bachmeier, R. M. Rabin, 2007: A Quantitative Analysis of the Enhanced-V Feature in Relation to Severe Weather, Weather and Forecasting, Volume 22, Issue 4 (August 2007) 853-87.

Burgess, D. W., R. J. Donaldson JR., and P. R. Desrochers, 1993: Tornado detection and warning by radaR. The Tornado: Its Structure, Dynamics, Prediction, and Hazards, Geophys. Monogr., No. 79, Amer. Geophys. Union, 203-221.

Byko, Z., P. Markowski, Y. Richardson, J. Wurman, E. Adlerman, 2009: Descending Reflectivity Cores in Supercell Thunderstorms Observed by Mobile Radars and in a High-Resolution Numerical Simulation, Weather and Forecasting, Volume 24, Issue 1 (February 2009) 155-18.

Chisholm, A. J. and J. Renick, 1972: The kinematics of multicell and supercell Alberta hailstorms, Alberta Hail Studies, 1972, Reseach Council of Alberta Hail Studies Rep. No. 72-2, 24-31.

Crane, R. K., 1979: Automatic cell detection and tracking. IEEE., Trans. Geosci. Electron., GE$17,250-262$.

Crum, T. D. and R. L. Alberty, 1993: The WSR-88D and the WSR-88D Operational Support Facility, Bulletin of the American Meteorological Society, Volume 74, Issue 9, 16691687.

Dance, S., E. Ebert, D. Scurrah, 2010: Thunderstorm Strike Probability Nowcasting, Journal of Atmospheric and Oceanic Technology, Volume 27, Issue 1) 79-9.

Dance, S., R. Potts, 2002: Microburst Detection Using Agent Networks, Journal of Atmospheric and Oceanic Technology, Volume 19, Issue 5) 646-65.

Davis, C., N. Atkins, D. Bartels, L. Bosart, M. Coniglio, G. Bryan, W. Cotton, D. Dowell, B. Jewett, R. Johns, D. Jorgensen, J. Knievel, K. Knupp, W. C. Lee, G. Mcfarquhar, J. Moore, R. Przybylinski, R. Rauber, B. Smull, R. Trapp, S. Trier, R. Wakimoto, M. Weisman, C. Ziegler, 2004: The Bow Echo and MCV Experiment: Observations and Opportunities, Bulletin of the American Meteorological Society, Volume 85, Issue 8 (August 2004) 1075-1093

Dixon, M. and G. Weiner, 1993: TITAN, Thunderstorm Identification, Tracking, Analysis and Nowcasting - A Radar-based Methodology, JAOT, 10, 785-797. 
Donaldson, Jr., Ralph J., P. R. Desrochers, 1990: Improvement of Tornado Warnings by Doppler Radar Measurement of Mesocyclone Rotational Kinetic Energy, Weather and Forecasting, Volume 5, Issue 2 (June 1990) 247-25.

Doswell III, C. A., 1980: Synoptic-Scale Environments Associated with High Plains Severe Thunderstorms, Bulletin of the American Meteorological Society, Volume 61, Issue 11 (November 1980) 1388-1400.

Doswell, C. A. III, 1982: The operational meteorology of convective weather, Volume I: Operational Mesoanalysis, NOAA Tech Memo ERL NSSFC-5, 168p.

Doswell, C. A. III, 1985: The operational meteorology of convective weather, Volume II: Storm Scale Analysis, NOAA Tech Memo ERL ESG-15, 240p.

Doswell III, C. A., 2001: Severe Convective Storms, Meteorological Monographs, Volume 28, 561pp.

Doswell III, C. A. 2004: Weather Forecasting by Humans - Heuristics and Decision Making. Weather and Forecasting 19:6, 1115-112.

Doswell III, C. A., R. Davies-Jones, D. L. Keller, 1990: On Summary Measures of Skill in Rare Event Forecasting Based on Contingency Tables, Weather and Forecasting, Volume 5, Issue 4 (December 1990) 576-58.

Doswell III, C. A., R. Edwards, R. L. Thompson, J. A. Hart, K. C. Crosbie, 2006: A Simple and Flexible Method for Ranking Severe Weather Events, Weather and Forecasting, Volume 21, Issue 6 (December 2006) 939-95.

Doswell III, C. A., A. R. Moller, H. E. Brooks, 1999: Storm Spotting and Public Awareness since the First Tornado Forecasts of 1948, Weather and Forecasting, Volume 14, Issue 4 (August 1999) 544-557.

Doviak, R. J., and D. S. Zrnic, 1984: Doppler Radar and weather observations, Academic Press, 458p.

Dunn, L. B., 1990: Two Examples of Operational Tornado Warnings Using Doppler Radar Data, Bulletin of the American Meteorological Society, Volume 71, Issue 2 (February 1990) 145-15.

Ebert, E. E., L. J. Wilson, B. G. Brown, P. Nurmi, H. E. Brooks, J. Bally, M. Jaeneke, 2004: Verification of Nowcasts from the WWRP Sydney 2000 Forecast Demonstration Project, Weather and Forecasting, Volume 19, Issue 1 (February 2004) 73-96

Eilts, M. D., and Coauthors, 1996: Severe weather warning decision support system. Preprints, 18th Conf. on Severe Local Storms, San Francisco, CA, AmeR. MeteoR. Soc., 536-540.

Evans, J. S., C. A. Doswell III, 2001: Examination of Derecho Environments Using Proximity Soundings, Weather and Forecasting, Volume 16, Issue 3 (June 2001) 329-34.

Fawbush, E. J. and R. C. Miller, 1953: Forecasting Tornadoes, USAF Air University Quarterly Review, 1, 108-11.

Fox, Neil I., R. Webb, J. Bally, M. W. Sleigh, C. E. Pierce, D. M. L. Sills, P. I. Joe, J. Wilson, C. G. Collier, 2004: The Impact of Advanced Nowcasting Systems on Severe Weather Warning during the Sydney 2000 Forecast Demonstration Project: 3 November 2000, Weather and Forecasting, Volume 19, Issue 1 (February 2004) 97-114

Frame, J., P. Markowski, Y. Richardson, J. Straka, J. Wurman, 2009: Polarimetric and DualDoppler Radar Observations of the Lipscomb County, Texas, Supercell Thunderstorm on 23 May 2002, Monthly Weather Review, Volume 137, Issue 2 (February 2009) 544-56. 
Galway, J. G., 1989: The Evolution of Severe Thunderstorm Criteria within the Weather Service, Weather and Forecasting, Volume 4, Issue 4 (December 1989) 585-59.

Gatlin, P. N., S. J. Goodman, 2010: A Total Lightning Trending Algorithm to Identify Severe Thunderstorms, Journal of Atmospheric and Oceanic Technology, Volume 27, Issue 1 (January 2010) 3-22.

Glahn, B., 2005: Tornado-Warning Performance in the Past and Future-Another Perspective, Bulletin of the American Meteorological Society, Volume 86, Issue 8 (August 2005) 1135-114.

Goodman, S. J., D. E. Buechler, P. J. Meyer, 1988: Convective Tendency Images Derived from a Combination of Lightning and Satellite Data, Weather and Forecasting, Volume 3, Issue 3 (September 1988) 173-188.

Hammer, B., T. W. Schmidlin, 2002: Response to Warnings during the 3 May 1999 Oklahoma City Tornado: Reasons and Relative Injury Rates, Weather and Forecasting, Volume 17, Issue 3 (June 2002) 577-58.

Heinselman, P. L., D. L. Priegnitz, K. L. Manross, T. M. Smith, R. W. Adams, 2008: Rapid Sampling of Severe Storms by the National Weather Radar Testbed Phased Array Radar, Weather and Forecasting, Volume 23, Issue 5 (October 2008) 808-824.

Hengstebeck, T., D. Heizenreder, P. Joe, P. Lang, 2011: The Mesocyclone Detection Algorithm of DWD, $6^{\text {th }}$ European Conference on Severe Storms, ECSS, 3-7 October 2011, Palma de Mallorca

Hermes, L. G., A. Witt, S. D. Smith, D. Klingle-Wilson, D. Morris, G. J. Stumpf, M. D. Eilts, 1993: The Gust-Front Detection and Wind-Shift Algorithms for the Terminal Doppler Weather Radar System, Journal of Atmospheric and Oceanic Technology, Volume 10, Issue 5 (October 1993) 693-70.

Hering, A. M., S. Senesi, P. Ambrosetti and I. Bernard-Bouissieres, 2005: Nowcasting thunderstorms in complex cases using radar data, WMO Symposium on Nowcasting and Very Short Range Forecasting, Toulouse France, paper 2. 14.

Hoekstra, S., K. Klockow, R. Riley, J. Brotzge, H. Brooks, S. Erickson, 2011: A Preliminary Look at the Social Perspective of Warn-on-Forecast: Preferred Tornado Warning Lead Time and the General Public's Perceptions of Weather Risks, Weather, Climate, and Society, Volume 3, Issue 2 (April 2011) 128-14.

Holleman, I. and H. Beekhuis, 2003: Analysis and correction of dual PRF velocity data, JAOT, 20(4), 443-453.

Honda, Y., M. Nishijima, K. Koizumi, Y. Ohta, K. Tamiya, T. Kawabata and T. Tsuyuki, 2005: A pre-operational variational data assimilation system for a non-hydrostatic model at the Japan Meteorological Agency: Formulation and preliminary results. Quart. J. Roy. Meteor. Soc., 131, 3465-3475.

James, P. M., S. Treple, D. Heizenreder and B. K. Reichert, 2011: NowCastMIX - A fuzzy logic based tool for providing automatic integrated nowcasting systems, 11th EMS Annual Meeting, 10th European Conference on Applications of Meteorology, 12-16 Sept 2011., EMS2011-234,

Joe, P., 2009: A First Look at Radar Data Quality for the Beijing 2008 Forecast Demonstration Project, in Collection of Papers on the New Generation of China Radars, (Xin Yi Dai, Tian Qi Leida Yewu Yingyoung Lunwenji, ISBN 978-7-5029-4468-1), edited by Xaioding $\mathrm{Yu}$ (invited lead paper). 
Joe, P., D. Burgess, R. Potts, T. Keenan, G. Stumpf, A. Treloar, 2004: The S2K Severe Weather Detection Algorithms and Their Performance, Weather and Forecasting, Volume 19, Issue 1, 43-63.

Joe, P., M. Falla, P. Van Rijn, L. Stamadianos, T. Falla, D. Magosse, L. Ing and J. Dobson, 2002: Radar Data Processing for Severe Weather in the National Radar Project of Canada, SELS, San Antonio, 12-16 August 2002, 221-224.

Joe, P., P. T. May, 2003: Correction of Dual PRF Velocity Errors for Operational Doppler Weather Radars, Journal of Atmospheric and Oceanic Technology, Volume 20, Issue 4 (April 2003) 429-44.

Johns, R. H., C. A. Doswell III, 1992: Severe Local Storms Forecasting, Weather and Forecasting, Volume 7, Issue 4 (December 1992) 588-61.

Johnson, J. T., P. L. MacKeen, A. Witt, E. De W. Mitchell, G. J. Stumpf, M. D. Eilts, K. W. Thomas., 1998: The Storm Cell Identification and Tracking Algorithm: An Enhanced WSR-88D Algorithm, Weather and Forecasting, Volume 13, Issue 2, 26327.

Keenan, T., P. Joe, J. Wilson, C. Collier, B. Golding, D. Burgess, P. May, C. Pierce, J. Bally, A. Crook, A. Seed, D. Sills, L. Berry, R. Potts, I. Bell, N. Fox, E. Ebert, M. Eilts, K. O'Loughlin, R. Webb, R. Carbone, K. Browning, R. Roberts, C. Mueller, 2004: The Sydney 2000 World Weather Research Programme Forecast Demonstration Project: Overview and Current Status, Bulletin of the American Meteorological Society, Volume 84, Issue 8, 1041-1054.

Kessler, E., J. W. Wilson, 1971: Radar in an Automated National Weather System, Bulletin of the American Meteorological Society, Volume 52, Issue 11, 1062-106.

King, P. W. S., M. J. Leduc, D. M. L. Sills, N. R. Donaldson, D. R. Hudak, P. Joe, B. P. Murphy, 2003: Lake Breezes in Southern Ontario and Their Relation to Tornado Climatology, Weather and Forecasting, Volume 18, Issue 5 (October 2003) 795-807.

Kitzmiller, D. H., W. E. McGovern, R. F. Saffle, 1995: The WSR-88D Severe Weather Potential Algorithm, Weather and Forecasting, Volume 10, Issue 1 (March 1995) 141-15.

Klingle, D. L., D. R. Smith, M. M. Wolfson, 1987: Gust Front Characteristics as Detected by Doppler Radar, Monthly Weather Review, Volume 115, Issue 5 (May 1987) 905-91.

Knupp, K. R., S. Paech, S. Goodman, 2003: Variations in Cloud-to-Ground Lightning Characteristics among Three Adjacent Tornadic Supercell Storms over the Tennessee Valley Region, Monthly Weather Review, Volume 131, Issue 1 (January 2003) 172-188

Koppert, H. -J., Pedersen, T. S., Zuercher, B., Joe, P., 2004: How to make an international Meteorological Workstation project successful, BAMS, 1087-109.

Lakshmanan, J. T. ., A. Fritz, T. Smith, K. Hondl, and G. J. Stumpf, 2007: An automated technique to quality control radar reflectivity data, J. Applied Meteorology, vol. 46, 288-305.

Lakshmanan, V., K. Hondl, and R. Rabin, 2009: An efficient, general-purpose technique for identifying storm cells in geospatial images, J. Ocean. Atmos. Tech., vol. 26, no. 3, 523-37.

Lakshmanan, V., R. Rabin, and V. DeBrunner, 2003: Multiscale storm identification and forecast, J. Atm. Res., vol. 67, 367-380.

Lakshmanan, V. and T. Smith, 2009: Data mining storm attributes from spatial grids, J. Ocea. and Atmos. Tech., vol. 26, no. 11, 2353-2365. 
Lakshmanan, V. and T. Smith, 2010: An Objective Method of Evaluating and Devising Storm-Tracking Algorithms, Weather and Forecasting, Volume 25, 701-709.

Lakshmanan, V., T. Smith, K. Hondl, G. J. Stumpf, A. Witt, 2006: A Real-Time, ThreeDimensional, Rapidly Updating, Heterogeneous Radar Merger Technique for Reflectivity, Velocity, and Derived Products, Weather and Forecasting, Volume 21, Issue 5, 802-82.

Lakshmanan, V., T. Smith, G. Stumpf, K. Hondl, 2007: The Warning Decision Support System-Integrated Information, Weather and Forecasting, Volume 22, Issue 3, 59661.

Lakshmanan, V., J. Zhang, K. Hondl, and C. Langston, 2011: A statistical approach to mitigating persistent clutter in radar reflectivity data, IEEE J. Selected Topics in Applied Earth Observations and Remote Sensing, vol. s, p. accepted.

Lakshmanan, V., J. Zhang, and K. Howard, 2010, A technique to censor biological echoes in radar reflectivity data, J. Applied Meteorology, vol. 49, 435-462.

Lang, P., 2001: Cell tracking and warning indicators derived from operational radar products, 30th International Radar Conference, AMS, Munich, Germany, 245-247.

Lang, T. J., L. J. Miller, M. Weisman, S. A. Rutledge, L. J. Barker III, V. N. Bringi, V. Chandrasekar, A. Detwiler, N. Doesken, J. Helsdon, C. Knight, P. Krehbiel, Walter A. Lyons, D. Macgorman, E. Rasmussen, W. Rison, W. D. Rust, Ronald J. T., 2004: The Severe Thunderstorm Electrification and Precipitation Study, Bulletin of the American Meteorological Society, Volume 85, Issue 8 (August 2004) 1107-1125

Lapczak, S., E. Aldcroft, M. Stanley-Jones, J. Scott, P. Joe, P. Van Rijn, M. Falla, A. Gagne, P. Ford, K. Reynolds and D. Hudak, 1999: The Canadian National Radar Project, 29th Conf. Radar Met., Montreal, AMS, 327-330.

Leduc, M., P. Joe, M. Falla, P. Van Rijn, S. Lapczak, I. Ruddick, A. Ashton and R. Alsen, 2002: The July 42001 Severe Weather Outbreak in Southern Ontario as Diagnosed by the New Radar Data Processing System of the National Radar Project of Canada, SELS, San Antonio, 12-16 August 2002, 170-173.

Lei H., S. Fu, L. Zhao, Y. Zheng, H. Wang and Y. Lin, 2009: 3D Convective Storm Identification, Tracking, and Forecasting - An Enhanced TITAN Algorithm, Journal of Atmospheric and Oceanic Technology, 2009: Volume 26, Issue 4) 719-73.

Lemon, L. R., 1977: new severe thunderstorm radar identification techniques are warning criteria: a preliminary report, NWS NSSFC-1, PB 273049 60p.

Lemon, L. R., 1980: new severe thunderstorm radar identification techniques are warning criteria, NWS NSSFC-1, PB 231409 60p.

Lemon, L. R., 1998: The Radar "Three-Body Scatter Spike": An Operational Large-Hail Signature, Weather and Forecasting, Volume 13, Issue 2 (June 1998) 327-34.

Lemon, L. R., Ralph J. Donaldson, Jr., D. W. Burgess, R. A. Brown, 1977: Doppler Radar Application to Severe Thunderstorm Study and Potential Real-Time Warning, Bulletin of the American Meteorological Society, Volume 58, Issue 11, 1187-119.

Lemon, L. R., C. A. Doswell III, 1979: Severe Thunderstorm Evolution and Mesocyclone Structure as Related to Tornadogenesis, Monthly Weather Review, Volume 107, Issue 9 (September 1979) 1184-119.

Lenning, E., H. E. Fuelberg, A. I. Watson, 1998: An Evaluation of WSR-88D Severe Hail Algorithms along the Northeastern Gulf Coast, Weather and Forecasting, Volume 13, Issue 4 (December 1998) 1029-104. 
Li, P.W. 2009: Development of a thunderstorm nowcasting system for Hong Kong International Airport, AMS Aviation, Range, Aerospace Meteorology Special Symposium on Weather-Air Traffic Management Integration, Phoenix, Arizona, 1115 Jan 2009.

Li, P. W. and W.K. Wong, 2010: Development of an Advanced Aviation Nowcasting System by Including Rapidly Updated NWP Model in Support of Air Traffic Management, Proceedings 14th Conference on Aviation, Range and Aerospace Meteorology, Atlanta, Georgia, USA, 17-21 January 2010.

Li, L., W. Schmid and J. Joss, 1995: Nowcasting of motion and growth of precipitation with radar over a complex orography, JAM, 34(6), 1286-1300

Li, P. W. and S. T. Lai, 2004: Applications of radar-based nowcasting techniques for mesoscale weather forecasting in Hong Kong, Meteorological Applications, 11, 253 264.

Li, P. W. and S. T. Lai, 2004a: Short-range quantitative precipitation forecasting in Hong Kong, Journal of Hydrology, 288, 189-209.

Li, P.W., W.K. Wong and E.S.T. Lai, 2005: A New Thunderstorm Nowcasting System in Hong Kong, WMO/WWRP International Symposium on Nowcasting and Veryshort-range Forecasting, Toulouse, France, 5-9 Sep. 2005.

Markowski, P. M., 2002: Hook Echoes and Rear-Flank Downdrafts: A Review, Monthly Weather Review, Volume 130, Issue 4 (April 2002) 852-87.

Markowski, P. M., E. N. Rasmussen, J. M. Straka, 1998a: The Occurrence of Tornadoes in Supercells Interacting with Boundaries during VORTEX-95, Weather and Forecasting, Volume 13, Issue 3 (September 1998) 852-85.

Markowski, P. M., J. M. Straka, E. N. Rasmussen, D. O. Blanchard, 1998b: Variability of Storm-Relative Helicity during VORTEX, Monthly Weather Review, Volume 126, Issue 11 (November 1998) 2959-297.

Marshall, J. S. and E. H. Ballantyne, 1975: Weather Surveillance Radar, J. A. M., 14, 13171338.

May, P. T., T. D. Keenan, R. Potts, J. W. Wilson, R. Webb, A. Treloar, E. Spark, S. Lawrence, E. Ebert, J. Bally, P. Joe, 2004: The Sydney 2000 Olympic Games Forecast Demonstration Project: Forecasting, Observing Network Infrastructure, and Data Processing Issues, Weather and Forecasting, Volume 19, Issue 1, 115-130.

McCarthy, J., J. W. Wilson, T. T. Fujita, 1982: The Joint Airport Weather Studies Project, Bulletin of the American Meteorological Society, Volume 63, Issue 1) 15-1.

McLaughlin, D., D. Pepyne, B. Philips, J. Kurose, M. Zink, D. Westbrook, E. Lyons, E. Knapp, A. Hopf, A. Defonzo, R. Contreras, T. Djaferis, E. Insanic, S. Frasier, V. Chandrasekar, F. Junyent, N. Bharadwaj, Y. Wang, Y. Liu, B. Dolan, K. Droegemeier, J. Brotzge, M. Xue, K. Kloesel, K. Brewster, F. Carr, S. Cruz-Pol, K. Hondl, P. Kollias, 2009: Short-Wavelength Technology and the Potential For Distributed Networks of Small Radar Systems, Bulletin of the American Meteorological Society, Volume 90, Issue 12, 1797-1817.

Melnikov, V. M., D. W. Burgess, D. L. Andra JR., M. P. Foster, J. M. Krause, 2005: K. A. Scharfenberg, D. J. Miller, Terry J. Schuur, P. T. Schlatter, Scott E. Giangrande, 2005: The Joint Polarization Experiment: Polarimetric Radar in Forecasting and Warning Decision Making, Weather and Forecasting, Volume 20, 775-78. 
Mercer, A. E., Chad M. Shafer, C. A. Doswell III, Lance M. L., M. B. Richman, 2009: Objective Classification of Tornadic and Nontornadic Severe Weather Outbreaks, Monthly Weather Review, Volume 137, Issue 12 (December 2009) 4355-436.

Mitchell, E. De W., S. V. Vasiloff, G. J. Stumpf, A. Witt, M. D. Eilts, J. T. Johnson, K. W. T., 1998: The National Severe Storms Laboratory Tornado Detection Algorithm, Weather and Forecasting, Volume 13, Issue 2, 352-36.

Moller, A. R., 1978: The Improved NWS Storm Spotters' Training Program at Ft. Worth, Tex., Bulletin of the American Meteorological Society, Volume 59, Issue 12 (December 1978) 1574-1582

Moller, A. R., 2001: Severe Local Storms Forecasting, Meteorological Monographs, Volume 28, Issue 50 (November 2001) 433-480

Moller, A. R., C. A. Doswell III, M. P. Foster, G. R. Woodall, 1994: The Operational Recognition of Supercell Thunderstorm Environments and Storm Structures, Weather and Forecasting, Volume 9, Issue 3, 327-347

Moninger, W. R., C. Lusk, W. F. R. s, J. Bullas, B. de Lorenzis, J. C. McLeod, E. Ellison, J. Flueck, P. D. Lampru, K. C. Young, J. Weaver, R. S. Philips, R. Shaw, T. R. Stewart, S. M. Zubrick, 1991: Shootout-89, A Comparative Evaluation of Knowledge-based Systems That Forecast Severe Weather, Bulletin of the American Meteorological Society, Volume 72, Issue 9 (September 1991) 1339-1354.

Monteverdi, J. P., C. A. Doswell III, G. S. Lipari, 2003: Shear Parameter Thresholds for Forecasting Tornadic Thunderstorms in Northern and Central California, Weather and Forecasting, Volume 18, Issue 2 (April 2003) 357-37.

O'Hora, Fritz and Joan Bech, 2007: Improving weather radar observations using pulsecompression techniques, Meteorological Applications, 14, 389-401.

Pliske, R., D. Klinger, R. Hutton, B. Crandall, B. Knight, and G. Klein, 1997: Understanding skilled weather forecasting: Implications for training and the design of forecasting tools. Contractor Rep. AL/HR-CR-1997-003, Material Command, Armstrong Laboratory, U. S. Air Force, 122

Polger, P. D., B. S. Goldsmith, R. C. Przywarty, J. R. Bocchieri, 1994: National Weather Service Warning Performance Based on the WSR-88D, Bulletin of the American Meteorological Society, Volume 75, Issue 2 (February 1994) 203-21.

Przybylinski, R. W., 1995: The Bow Echo: Observations, Numerical Simulations, and Severe Weather Detection Methods, Weather and Forecasting, Volume 10 (2) 203-21.

Rasmussen. E. N., 2003: Refined Supercell and Tornado Forecast Parameters. Weather and Forecasting 18:3, 530-53.

Rasmussen, E. N., J. M. Straka, R. Davies-Jones, C. A. Doswell III, F. H. Carr, M. D. Eilts, D. R. MacGorman, 1994: Verification of the Origins of Rotation in Tornadoes Experiment: VORTEX, Bulletin of the American Meteorological Society, Volume 75, Issue 6 (June 1994) 995-100.

Ruzanski, E., V. Chandrasekar, Y. Wang, 2011: The CASA Nowcasting System. Journal of Atmospheric and Oceanic Technology, 28, 640-65.

Roberts, Rita D., D. Burgess, M. Meister, 2006: Developing Tools for Nowcasting Storm Severity, Weather and Forecasting, Volume 21, 540-55.

Saffle, R. E., 1976: D/RADEX products and field operation. 17th Conf. on Radar Meteorology, Seattle, AMS, Boston, MA., 555-559. 
Schaefer, J. T., 1990: The Critical Success Index as an Indicator of Warning Skill, Weather and Forecasting, Volume 5, 570-57.

Schmeits, M. J., Kees J. Kok, D. H. P. Vogelezang, R. M. van Westrhenen, 2008: Probabilistic Forecasts of (Severe) Thunderstorms for the Purpose of Issuing a Weather Alarm in the Netherlands, Weather and Forecasting, Volume 23, Issue 6 (December 2008) 1253-126.

Schultz, C. J., W. A. Petersen, L. D. Carey, 2011: Lightning and Severe Weather: A Comparison between Total and Cloud-to-Ground Lightning Trends, Weather and Forecasting, Volume 26, Issue 5 (October 2011) 744-75.

Schumacher, R. S., D. T. Lindsey, A. B. Schumacher, J. Braun, S. D. Miller, J. L. Demuth, 2010: Multidisciplinary Analysis of an Unusual Tornado: Meteorology, Climatology, and the Communication and Interpretation of Warnings, Weather and Forecasting, Volume 25, 1412-142.

Serafin, R. J., J. W. Wilson, 2000: Operational Weather Radar in the United States: Progress and Opportunity, Bulletin of the American Meteorological Societ.

Sills, D. M. L., J. W. Wilson, P. I. Joe, D. W. Burgess, R. M. Webb, N. I. Fox, 2004: The 3 November Tornadic Event during Sydney 2000: Storm Evolution and the Role of Low-Level Boundaries, Weather and Forecasting, Volume 19, Issue 1, February 2004) 22-42

Smith, P. L., 1999: Effects of Imperfect Storm Reporting on the Verification of Weather Warnings, Bulletin of the American Meteorological Society, Volume 80, 1099-110.

Stensrud, D. J., L. J. Wicker, K. E. Kelleher, M. Xue, M. P. Foster, J. T. Schaefer, R. S. Schneider, S. G. Benjamin, S. Weygandt, J. T. Ferree, J. P. Tuell, 2009: ConvectiveScale Warn-on-Forecast System, Bulletin of the American Meteorological Society, Volume 90, 1487-149.

Stumpf, G. J., A. Witt, E. DeW. Mitchell, P. Spencer, J. T. Johnson, M. D. Eilts, K. W. Thomas, D. W. Burgess, 1998: The National Severe Storms Laboratory Mesocyclone Detection Algorithm for the WSR-88D, Weather and Forecasting, Volume 13, 30432.

Sun, J., and N. A. Crook, 1994: Wind and thermodynamic retrieval from single-Doppler measurements of a gust front observed during Phoenix-II. Mon. Wea. Rev., 122, 1075-1091.

Sun, J., D. Flicker, and D. K. Lilly, 1991: Recovery of three-dimensional wind and temper 7 ature from simulated single-Doppler radar data. J. Atmos. Sci., 48, 876-890.

Uyeda, H. and D. S. Zrnic, 1986: Automatic Detection of Gust Fronts, Journal of Atmospheric and Oceanic Technology, Volume 3, 36-5.

Vasiloff, S. V., 2001: Improving Tornado Warnings with the Federal Aviation Administration's Terminal Doppler Weather Radar, Bulletin of the American Meteorological Society, Volume 82, 861-87.

Wang, H. K., R. Mercer, J. Baron and P. Joe, 2011: Skeleton-based hook echo detection in radar reflectivity data, J. Tech, submitted.

Wang, J. J., T. Keenan, P. Joe, J. Wilson, E. S. T. Lai, F. Liang, Y. Wang, B. Ebert, Q. Ye, J. Bally, A. Seed, M. X. Chen, J. Xue, B. Conway, 2010: Overview of the Beiijing 2008 Olympics Forecast Demonstration Project, China Meteorological Press, 145pp. 
Wasula, A. C., L. F. Bosart, K. D. LaPenta, 2002: The Influence of Terrain on the Severe Weather Distribution across Interior Eastern New York and Western New England, Weather and Forecasting, Volume 17, Issue 6 (December 2002) 1277-1289.

Weiss, S. J., C. A. Doswell III, F. P. Ostby, 1980: Comments on Automated 12-36 Hour Probability Forecasts of Thunderstorms and Severe Local Storms, Journal of Applied MeteorologyVolume 19, Issue 11, 1328-1333.

Weisman, M. L., 2001: Bow Echoes: A Tribute to T. T. Fujita, Bulletin of the American Meteorological Society, Volume 82, 97-116

Weisman, M. L., J. B. Klemp, 1984: The Structure and Classification of Numerically Simulated Convective Stormsin Directionally Varying Wind Shears, Monthly Weather Review, Volume 112, Issue 12 (December 1984) 2479-2498

Weisman, M. L., R. Rotunno, 2000: The Use of Vertical Wind Shear versus Helicity in Interpreting Supercell Dynamics, Journal of the Atmospheric Sciences, Volume 57, Issue 9 (May 2000) 1452-1472

Weisman, M. L., R. Rotunno, 2004: “A Theory for Strong Long-Lived Squall Lines" Revisited, Journal of the Atmospheric Sciences, Volume 61, Issue 4 (February 2004) 361-382

Westefeld, J. S., A. R. Less, T. Ansley, H.S. Yi, 2006: Severe-Weather Phobia, Bulletin of the American Meteorological Society, 2006: Volume 87, 747-74.

Wilson, J. W., E. A. Brandes, 1979: Radar Measurement of Rainfall-A Summary, Bulletin of the American Meteorological Society, Volume 60, 1048-105.

Wilson, J., R. Carbone, H. Baynton, R. Serafin, 1980: Operational Application of Meteorological Doppler Radar, Bulletin of the American Meteorological Society, Volume 61, 1154-116.

Wilson, J. W., N. A. Crook, C. K. Mueller, J. Sun, M. Dixon, 1998: Nowcasting Thunderstorms: A Status Report, Bulletin of the American Meteorological Society, Volume 79, 2079-209.

Wilson, J. W., E. E. Ebert, T. R. Saxen, R. D. Robertss, C. K. Mueller, M. Sleigh, C. E. Pierce, A. Seed, 2004: Sydney 2000 Forecast Demonstration Project: Convective Storm Nowcasting, Weather and Forecasting, Volume 19, 131-15.

Wilson, J. W., Y. Feng, Min Chen, Rita D. R. s, 2010: Nowcasting Challenges during the Beijing Olympics: Successes, Failures, and Implications for Future Nowcasting Systems, Weather and Forecasting, Volume 25, 1691-171.

Wilson, J. W., J. A. Moore, G. B. Foote, B. Martner, T. Uttal, J. M. Wilczak, A. R. Rodi, 1988: Convection Initiation and Downburst Experiment (CINDE), Bulletin of the American Meteorological Society, Volume 69, 1328-134.

Wilson, J. W., R. M. Wakimoto, 2001: The Discovery of the Downburst: T. T. Fujita's Contribution, Bulletin of the American Meteorological Society, Volume 82, 49-6.

Winston, H. A., 1998: A Comparison of Three Radar-Based Severe-Storm-Detection Algorithms on Colorado High Plains Thunderstorms, Weather and Forecasting, Volume 3, 131-140.

Winston, H. A., L. J. Ruthi, 1986: Evaluation of RADAP II Severe-Storm-Detection Algorithms, Bulletin of the American Meteorological Society, Volume 67, 145-15.

Witt, A., M. D. Eilts, G. J. Stumpf, J. T. Johnson, E. De W. Mitchell, K. W. T., 1998a: An Enhanced Hail Detection Algorithm for the WSR-88D, Weather and Forecasting, Volume 13, 286-30. 
Witt, A., M. D. Eilts, G. J. Stumpf, E. De W. Mitchell, J. T. Johnson, K. W. T., 1998b: Evaluating the Performance of WSR-88D Severe Storm Detection Algorithms, Weather and Forecasting, Volume 13, 513-51.

WMO, 2008: Commission on Instruments, Methods and Observations Guide, Chapter 9, 7th edition, available at http://www.wmo.int/pages/prog/www/IMOP/publications/CIMOGuide/CIMO\%20Guide\%207th\%20Edition,\%202008/Part\%20II/Chapter\%209. pdf

Wong, W. K., L. H. Y. Yeung, Y. C. Wang \& M. Chen, 2009: Towards the Blending of NWP with Nowcast - Operation Experience in B08FDP, WMO Symposium on Nowcasting, 30 Aug-4 Sep 2009, Whistler, B. C., Canada.

Wong K. Y., C. L. Yip and P. W. Li, 2007: A Novel Algorithm for Automatic Tropical Cyclone Eye Fix Using Doppler Weather Radar, Meteorological Applications, 14, 49-5.

Yeung, L. H. Y., E. S. T. Lai \& P. K. Y. Chan, 2008: Thunderstorm Downburst and Radarbased Nowcasting of Squalls, the Fifth European Conference on Radar in Meteorology and Hydrology, Helsinki, Finland 30 June - 4 July 200.

Yeung, L. H. Y., W. K. Wong, P. K. Y. Chan \& E. S. T. Lai, 2009: Applications of the Hong Kong Observatory nowcasting system SWIRLS-2 in support of the 2008 Beijing Olympic Games. WMO Symposium on Nowcasting, 30 Aug-4 Sep 2009, Whistler, B. C., Canada.

Yeung, L. H. Y., E. S. T. Lai \& S. K. S. Chiu, 2007: Lightning Initiation and Intensity Nowcasting Based on Isothermal Radar Reflectivity - A Conceptual Model, the 33rd International Conference on Radar Meteorology, Cairns, Australia, 6-10 August 2007.

Zipser, E. J., C. Liu, D. J. Cecil, S. W. Nesbitt, D. P. Yorty, 2006: Where are the most intense thunderstorms on Earth?, BAMS, 87 (8), 1057-1071.

Zrnic, D. S., D. W. Burgess, L. D. Hennington, 1985: Automatic Detection of Mesocyclonic Shear with Doppler Radar, Journal of Atmospheric and Oceanic Technology, Volume 2, 425-438. 




\author{
Doppler Radar Observations - Weather Radar, Wind Profiler, \\ lonospheric Radar, and Other Advanced Applications \\ Edited by Dr. Joan Bech
}

ISBN 978-953-51-0496-4

Hard cover, 470 pages

Publisher InTech

Published online 05, April, 2012

Published in print edition April, 2012

Doppler radar systems have been instrumental to improve our understanding and monitoring capabilities of phenomena taking place in the low, middle, and upper atmosphere. Weather radars, wind profilers, and incoherent and coherent scatter radars implementing Doppler techniques are now used routinely both in research and operational applications by scientists and practitioners. This book brings together a collection of eighteen essays by international leading authors devoted to different applications of ground based Doppler radars. Topics covered include, among others, severe weather surveillance, precipitation estimation and nowcasting, wind and turbulence retrievals, ionospheric radar and volcanological applications of Doppler radar. The book is ideally suited for graduate students looking for an introduction to the field or professionals intending to refresh or update their knowledge on Doppler radar applications.

\title{
How to reference
}

In order to correctly reference this scholarly work, feel free to copy and paste the following:

Paul Joe, Sandy Dance, Valliappa Lakshmanan, Dirk Heizenreder, Paul James, Peter Lang, Thomas Hengstebeck, Yerong Feng, P.W. Li, Hon-Yin Yeung, Osamu Suzuki, Keiji Doi and Jianhua Dai (2012). Automated Processing of Doppler Radar Data for Severe Weather Warnings, Doppler Radar Observations Weather Radar, Wind Profiler, Ionospheric Radar, and Other Advanced Applications, Dr. Joan Bech (Ed.), ISBN: 978-953-51-0496-4, InTech, Available from: http://www.intechopen.com/books/doppler-radarobservations-weather-radar-wind-profiler-ionospheric-radar-and-other-advanced-applications/automatedprocessing-of-doppler-radar-data-for-severe-weather-forecasting

\section{INTECH}

open science | open minds

\section{InTech Europe}

University Campus STeP Ri

Slavka Krautzeka 83/A

51000 Rijeka, Croatia

Phone: +385 (51) 770447

Fax: +385 (51) 686166

www.intechopen.com

\section{InTech China}

Unit 405, Office Block, Hotel Equatorial Shanghai

No.65, Yan An Road (West), Shanghai, 200040, China 中国上海市延安西路65号上海国际贵都大饭店办公楼405单元

Phone: +86-21-62489820

Fax: $+86-21-62489821$ 
(C) 2012 The Author(s). Licensee IntechOpen. This is an open access article distributed under the terms of the Creative Commons Attribution 3.0 License, which permits unrestricted use, distribution, and reproduction in any medium, provided the original work is properly cited. 